\title{
NARODIŤ SA NESTAČÍ. \\ PERCEPCIA NAJMENŠÍCH DETÍ V ANTIKE V KONTEXTE VYBRANÝCH PÍSOMNÝCH A ARCHEOLOGICKÝCH PRAMEŇOV
}

\author{
Katarína Hladíková* - Lucie Vélová**
}

\author{
*Katedra archeológie, Filozofická fakulta UK, Gondova 2, 81102 Bratislava, katarina.bladikova@uniba.ske. \\ **Oddělení pravěku a antického starověku, Národní muzeum,Václavské námèstí 68,115 79 Praha 1, lucie.velova@nm.cz.
}

\begin{abstract}
The birth is not enough. The perception of the Youngest Children in Antiquity in the Context of Selected Written and Archaeological Sources. The paper deals with the issue of perception of the youngest children in ancient society in the context of selected written and archaeological sources in the wider territory of ancient Greece and the Roman Empire. The nature of historical sources and their fragmentation greatly complicate their interpretation. In this respect, archaeological sources also do not offer a clear answer as they show a high variability in the treatment of the remains of the youngest children. Nevertheless, the paper seeks to oppose the entirely negative perception of children widespread in the scientific literature that discusses mainly the works of philosophers, in which the youngest children are presented as lower beings similar to animals. Manifestations of parental love are documented primarily by private correspondence concerning the death of children, and also recorded on epigraphic monuments, in literary works and mythological stories. From the archaeological perspective, regular graves of the youngest children testify to the existence of care and love of the parents, whose manifestations, however, were subject to social norms.
\end{abstract}

Keywords: fetuses, newborns, infanticide, perception, antiquity, written and archaeological sources

\begin{abstract}
Abstrakt: Príspevok sa venuje problematike percepcie najmenších detí v antickej spoločnosti v kontexte vybraných písomných a archeologických prameňov v rámci širšieho priestoru antického Grécka a Ríma. Charakter historických prameňov a ich fragmentárnost' do značnej miery komplikujú ich interpretáciu. V tomto smere nám ani archeologické pramene neposkytujú jednoznačnú odpoved’, poukazujú totiž na širokú variabilitu v zaobchádzaní s pozostatkami najmenších detí. Napriek tomu sa v príspevku snažíme vymedzit' voči výlučne negatívnej percepcii detí často pertraktovanej v odbornej literatúre diskutujúcej najmä diela filozofov, v ktorých sú najmenšie deti prezentované ako nižšie bytosti pripodobované zvieratám. Prejavy rodičovskej lásky sú doložené predovšetkým v súkromnej korešpondencii dotýkajúcej sa práve smrti detí, ktorej dokladmi sú napr. aj epigrafické pamiatky, literárne diela a mytologické príbehy. Rovnako aj z archeologického hl’adiska regulárne hroby najmenších detí svedčia o existencii starostlivosti a láske vtedajších rodičov, ktorej prejavy však boli podriadené spoločenským normám.
\end{abstract}

Kl’účové slová: plody, novorodenci, infanticída, percepcia, antika, písomné a archeologické pramene

https://doi.org/10.46283/musarch.2020.1.03

\section{1. Úvod}

Problematika detí a detstva bola v minulosti v rámci historických vied a archeológie značne marginalizovaná. V posledných desat'ročiach sa tejto téme venuje čoraz viac bádatel’ov, teda predovšetkým bádateliek. Vd’aka tomuto vývoju sa objavujú postupne aj práce zamerané na parciálne aspekty a fenomény detskej problematiky. K takým patrí aj problematika percepcie najmenších detí, ktoré boli dlhodobo vo vedeckej literatúre zanedbávané. K významným 
dielam zaoberajúcim sa touto problematikou v antike patria články a publikácie V. Dasen (2003, 2004, 2008, 2009 a i.). Zásadné diela v tomto smere predstavujú: kompendium The Oxford Handbook of Childhood and Education in the Classical World (Evans Grubbs - Parkin 2013), monografie Infancy and Earliest Childhood in the Roman World. A Fragment of Time. od M. Caroll (2018) a staršia práca Cbildren and Cbildhood in Classical Athens M. Goldena (1990) a mnohé d’alšie.

Možnosti (re)konštrukcie postavenia a percepcie detí len na základe archeologických prameňov sú pomerne obmedzené, avšak spolupráca s d’alšími vednými odbormi prináša zaujímavé výsledky. Celosvetový rozkvet „archeológie detstva" otvoril možnosti a zdôraznil potrebu venovat' sa najmladšej vekovej skupine detailnejšie (pozri Vélová 2018 s d’alšou literatúrou). Raritné nálezy pozostatkov najmenších detí, t. j. ešte nenarodených plodov a novorodencov, pribúdajú (cf. Vélová - Hladíková - Dañová, v tlača), čo nepochybne súvisí s modernejšími metódami výskumu. Nové archeologické nálezy umožňujú konfrontovat' zodpovedajúce písomné pramene a zamýšlat' sa znovu nad zásadnými celospoločenskými témami, ako je vznik života, status fetusov a postavenie novorodencov, postihnutých jedincov a postavenie tehotných žien a matiek a pod.

Pre názornú ilustráciu, ktorej účelom je sprostredkovat’ širokú škálu percepcie malých detí v konkrétnej spoločnosti, sme využili výber z antických písomných prameňov a súvisiace archeologické nálezy detských pozostatkov. Ciel’om príspevku je poukázat' na značnú variabilitu vo vnímaní detí rôznych vekových kategórií, predovšetkým najmenších detí od nenarodených/potratených plodov po dojčatá do jedného roka v antike. Nedostatok prameňov popisujúcich, prípadne zobrazujúcich malé deti, rovnako ako aj často uvádzaný deficit ich pozostatkov v archeologických prameňoch (chýbajúce deti na pohrebiskách a sídliskách) sa pomerne často interpretuje ako absencia lásky $\mathrm{k}$ det’om, prípadne ich nedôležitost' pre spoločnost' do istého veku. Bolo tomu naozaj tak?

Napriek tomu, že tehotenstvo, pôrod a starostlivost' o malé deti boli doménou žien, hlavné aktérky nám priame svedectvo prostredníctvom písomných prameňov nezanechali. Pri štúdiu tejto témy musíme vychádzat' z informácií z diel mužských autorov, ktorí navyše väčšinou popisujú situáciu v slobodných a lepšie situovaných rodinách. V dielach antických autorov sa stretávame napr. s rozlišovaním jednotlivých fáz formovania plodu, tehotenstvom, pôrodom a tiež s polemikou o duši fetusov a o potratoch. Taktiež tu narážame na doporučenia týkajúce sa stanovenia vhodného veku dievčat na svadbu a následné počatie. Antickí lekári si totiž boli vedomí rizík spojených s graviditou a pôrodom u vel'mi mladých prvorodičiek.

Čo sa týka percepcie fetusov, predčasne narodených detí a novorodencov, prípadne detí do jedného roka, tak možno rozlišovat' medicínske charakteristiky autorov venujúcim sa medicínskemu aspektu (Hippokrates, Soranus, Galénos), zmienky týkajúce sa právnych otázok/sociálnych noriem a charakteristiky týchto jedincov v dielach filozofov (Platón, Aristoteles, Tertuliánus) a v neposlednom rade zmienky v dielach a korešpondencii historikov, básnikov a d'alších autorov (Plutarchos, Cicero, Seneca a i.).

\section{Tehotenstvo a vývoj plodu}

$\mathrm{Na}$ výpočet dížky tehotenstva existovali v starovekom Grécku medzi učencami rôzne názory (Tsoucalas - Sgantžos 2017). Dnešným znalostiam zodpovedala predstava Hippokrata (460 - 370 pred Kr.), pod’a ktorej tehotenstvo trvalo devät' kalendárnych mesiacov (alebo desat' lunárnych), alebo 280 dní (Stol 2000, 20; Malamitsi-Puchner 2017, 141). Donosené deti mali ovel’a lepšie vyhliadky na prežitie v porovnaní s det’mi prenosenými a narodenými predčasne. Predčasne narodené deti sa označovali ako „Elitomina“ (chýbajúce mesiace) a spomínajú sa deti narodené v šiestom, siedmom a ôsmom mesiaci (Malamitsi-Puchner - Briana 2017, 2-3). Všeobecne sa predpokladalo, že diet’a narodené $\mathrm{v}$ siedmom mesiaci je vitálnejšie, resp. má väčšiu šancu na prežitie ako diet’a narodené v ôsmom mesiaci (Dasen 2013a, 23; Stol 2000, 21-22). Hranica životaschopnosti plodu bola podla antických autorov stanovená vel'mi nízko - na 28, alebo dokonca 26 gestačných týždňov (Malamitsi-Puchner 2017, 142). Hippokrates pomerne presne uvádza aj príčiny predčasných pôrodov, spolu s Plutarchom (46 - 127 po Kr.) definuje i kategóriu detí s nízkou pôrodnou hmotnost'ou (small for gestational age - malé na svoj gestačný vek), ${ }^{1}$ jej príčiny a upozorňuje na ich vyššiu morbiditu (Malamitsi-Puchner 2017). Predčasne narodené deti - bohovia či héroovia - vystupujú i v gréckej mytológii, napr. Dio-

1 Určovanie veku detí s nízkou pôrodnou váhou je pre antropológov značne obtiažne, pretože je problematické ich odlíšenie od predčasne narodených detí (Halcrow - Tayles - Elliott 2018, 84-91). 


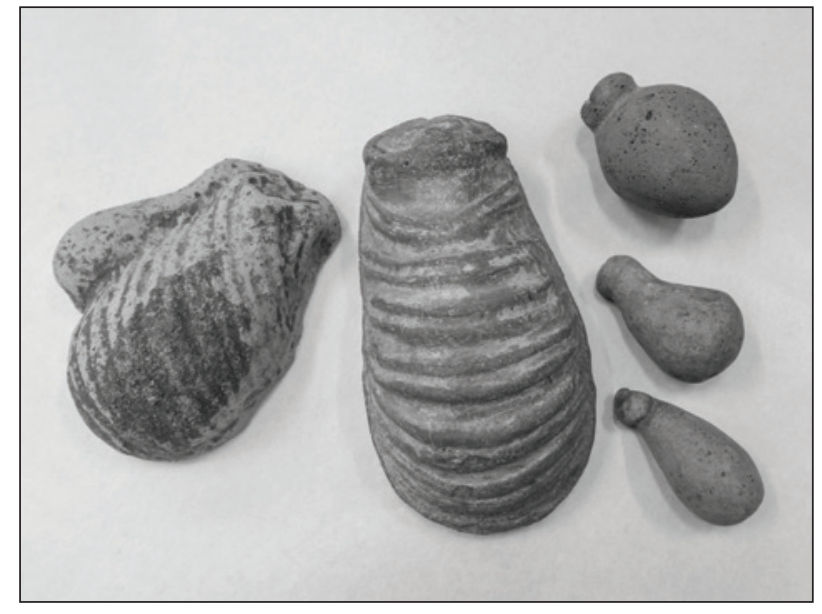

Obr. 1. Anatomické votíva materníc, Etrúria,

3. - 2. stor. pred Kr., zbierka Národního muzea (inv. č. H10-3855, H10-3856, H10-3857, H10-3374,

H10-6378). Foto: Lucie Vélová.

Fig. 1. Votive uteri, Etruria, 3.-2. century B.C., archaeological collection of National museum, Prague (inv. no. H10-3855, H10-3856, H10-3857, H10-3374, H10-6378). Photo: Lucie Vélová. nýzos či král Eurysteus (Kerényi 1996a; 1996b).

Je dôležité si uvedomit', že anatómia l’udského tela nebola detailnejšie známa zhruba do 3. stor. pred Kr., kedy sa začalo s prvými pitvami (napr. Hérofilos - 335 - 280 pred Kr.; Papaikonomou 2013, 113). Informácie o formovaní plodu v maternici získavali starí Gréci hlavne z telíčok potratených detí, resp. detí z predčasne ukončených tehotenstiev. Grécki autori rozlišujú niekol'ko fáz vývoja plodu in utero (viac pozri Dasen 2013a, 17-18). Galénos (129 - 210 po Kr.; Gal. De Sem. 4.5423) o vývoji plodu pojednáva asi najpodrobnejšie, pričom rozlišuje: gonè (spermia), kúèma (stává sa živou bytost'ou), kuoumenon zoon (začína byt' srdce), émbruon (formovanie sa telíčka), brephos (plod, bábätko) a paidíon (diet'a - hýbuce sa, môže platit' až pre deti do sedem rokov). V diele De natura pueri (Hipp., De Nat. Puer. 18, 7.498500) Hippokrates popisuje, že chlapci sú „sformovaní“ po 30 dňoch a dievčatá až po 42 dňoch, pretože tie sú slabšie a pomalšie a pod. Iné údaje uvádza Aristoteles (385 - 323 pred Kr.), ktorý síce tiež tvrdí, že vývoj plodu ženského pohlavia trvá (Hist. Anim. VII, 3, 583B) dlhšie - 90 dní - v porovnaní s vývojom plodu mužského pohlavia (40 dní; Stol 2000, 12-17), avšak tu v súvislosti s vývojom duše. Pre väčšinu autorov sa émbruon stáva živou bytost'ou s objavením sa prvých pohybov. U chlapcov to malo byt' v tret'om mesiaci a u dievčat vo štvrtom, prípadne neskôr (e.g. Hipp., De Nat. Puer. 21, 7.510-12).

Viacplodové tehotenstvo budilo v antike rozporuplné emócie. Takéto tehotenstvá boli vnímané bud’ ako požehnanie alebo ako ohavnost'. Známa bola aj ich vyššia rizikovost'. Existencia dvojčiat bola považovaná síce za vzácnu, ale stále ešte ako tak prijatel'nú situáciu, ked’že vychádzajúc z hippokratovských autorov maternica sa mohla rozdelit' a ženy majú dva prsníky, z ktorých je možné kŕmit' dve deti naraz. Avšak narodenie viac ako dvoch detí bolo považované už za anomáliu. Bolo chápané ako porušenie kozmického poriadku a zlé znamenie, a preto boli viacerčatá likvidované (Dasen 2013a, 20-23).

V podstate už od počatia boli deti a tehotné ženy zverované do ochrany božstiev, ktoré mali zaistit' bezproblémový priebeh tehotenstva a pôrodu (napr. votíva materníc - obr. 1). V Grécku išlo napr. o bohyňu Artemis Lochia a Eileithyiu, v Ríme zase Juno Lucinu či Candeliferu a d’alšie (Dasen 2013a, 31; Garland 2013, 208; Caroll 2018, 71). O tejto snahe svedčí prítomnost' rôznych ochranných amuletov v ženských a detských hroboch - aj u najmenších detí. Ich nosenie je doložené aj na ikonografických pamiatkach (obr. 2; Dasen 2018; Graham 2016; Hladíková 2018). Ochranná funkcia sa prisudzovala napr. aj pupočnej šnúre - nosenie jej zvyšku umiestnené v amulete malo diet'at'u zaručit' silu (Papaikonomon 2013, 128). Zobrazenia tehotných žien sú inak vcelku ojedinelé, ako príklad možno uviest’ dve výnimočné terakotové figúrky (obr. 3) sediacich žien s vyberatel’nými fetusmi z otváracieho brucha (Dasen 2013a, 30). Z obdobia rímskeho cisárstva pochádzajú zobrazenia plodov na magických polodrahokamoch, ktoré bývajú popísané ochrannými znakmi, formulami a prípadne sú na nich zobrazené postavy božstiev kombinované z egyptských či gréckorímskych prvkov (Dasen 2013a,31).

V súvislosti s fetusmi nemožno opomenút' ani problematiku zámerných potratov. V antickom Grécku a Ríme boli potraty plodov v podstate legálne, resp. akceptované, ked’že plody, rovnako ako novonarodené deti, neboli prijaté spoločnost'ou do ich legitimizácie otcom (Dasen 2011, 297; Czachorowski 2018, 572). Podl'a niektorých autorov bol potrat z morálneho hl'adiska prípustný, len pokial' plod nezačal nadobúdat' l’udské črty. Hippokrates sa k potratom stavia odmietavo z obavy o poškodenie zdravia žien, o osud plodu sa nezaujíma. Platón (427 - 347 pred Kr.) sa vo svojom diele Ústava (460 C; 461C) o ideálnom štáte nepriamo prikláňa k potratom a k infanticíde v prípade splodenia detí $\mathrm{v}$ rámci incestných vzt'ahov a $\mathrm{k}$ infanticíde $\mathrm{v}$ prípade neduživých detí alebo detí splodených rodičmi nevhodného pôvodu. Aristoteles rovnako uvažuje nad možnost'ou potratu, pokial je realizovaný v raných fázach tehotenstva, 


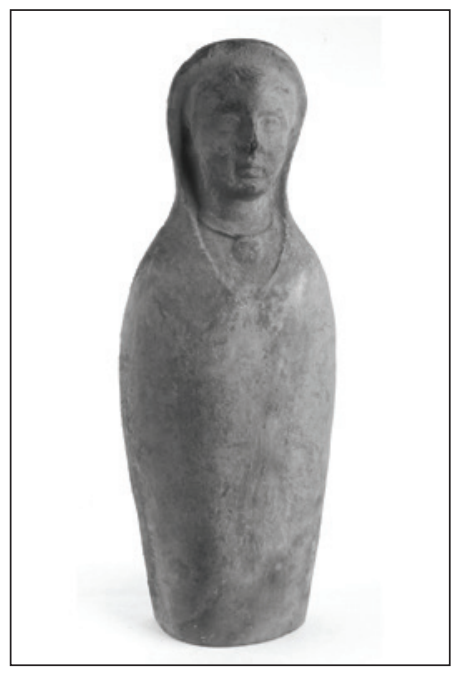

Obr. 2. Zavinuté dojča s amuletom, Etrúria, 3.-2. stor. pred Kr., zbierka Národního muzea (inv. č. H10-5600). Foto: Jiř́i Vaněk.

Fig. 2. Swaddled baby with amulet, Etruria, 3.-2. century B.C., archaeological collection of National museum, Prague (inv. no.

H10-5600). Photo: Jiří Vaněk.

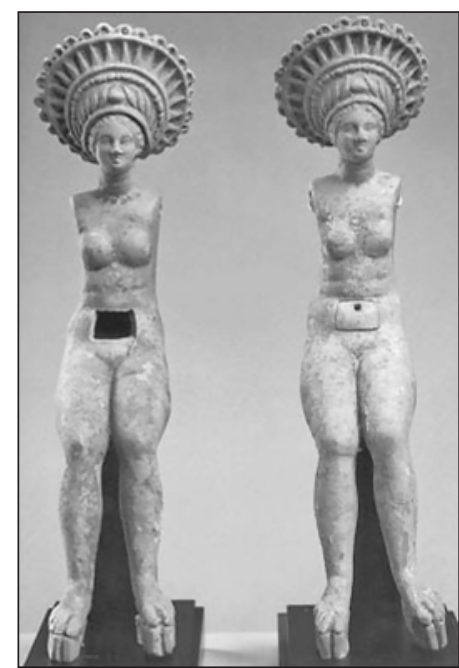

Obr. 3. Sediaca ženská soška s vyt'ahovacou postavičkou plodu (podl’a Dasen 2013a, 30, Fig. 1.3).

Fig. 3. Sitting woman's figurine with baby in the belly (according Dasen 2013a, 30, Fig. 1.3).

a nepovažuje ho za zabitie. Dokonca umelé potraty pokladá za riešenie, ak je príliš vysoká pôrodnost', ale len do fázy kým sa embryu „nezačínajú prebúdzat’ zmysly“ (Aristoteles Politika, 1335 b, 280-281; Czachorowski 2018, 572).

V Ríme bol fetus z legálneho hl’adiska považovaný za osobu, iba ak mal byt’ dedičom svojho otca. Po pôrode bolo diet'a rovnako pod právnou kontrolou otca, ktorý rozhodoval o jeho živote alebo smrti (Evans Grubbs 2013, 85). Podl’a raného rímskeho práva platilo, že diet’a v bruchu matky sa nepovažuje za osobu/človeka a Ulpianus uvádza, že plod je chápaný ako čast’ ženy alebo čast' jej vnútra (Ulpian, Dig. 24,1). Cicero (106 - 43 pred Kr.) považoval potrat za vraždu, ktorá môže byt' potrestaná zákonom. V mladšom diele ranokrest’anského filozofa Tertuliána (150 - 222 po Kr.; Apolog., IX, 8.) sú potraty považované za rovnocenné zabitiu človeka, lebo plod chápe ako potencionálnu ludskú bytost' (Czachorowski 2018, 568) a podobných príkladov by bolo možné uviest' viac.

Téma potratov je previazaná s polemikou o duši plodu. Podl’a Platóna plod získava dušu v momente narodenia pri prvom nádychu, čiže nie v maternici. Na inom mieste píše, že duša je z l’udského semena - túto nezrovnalost' kritizuje Tertulián (De anima, 25, 2-4). Podl'a Tertuliána (De anima, 25, 2; 37) má embryo dušu od momentu počatia a telo s dušou sa formujú súčasne. Aristoteles (De anima) predpokladá nadväznost' duší (rastlinná, živočíšna a rozumová, ktorá sa pripája v dobe, ked’ embryo získava l’udskú podobu, podl’a pohlavia plodu 40 či 80 dní po oplodnenî).

\section{Narodenie}

Antická spoločnost' si vel'mi dobre uvedomovala zdravotné riziká hroziace pri pôrode. Aj preto bol tento významný okamih v živote rodín považovaný za jeden z najkritickejších. V živote novorodenca ide zároveň o prvý zásadný prechodový rituál. ${ }^{2}$ Dôležitú úlohu hrali skúsené pôrodné babice (obr. 4), ktoré zvládali i menšie gynekologické zákroky; lekári boli k pôrodom privolávaní len pri komplikáciách (Karamanou et al. 2013). V antike sa bežne rodilo vaginálnym spôsobom, cisársky rez sa s najväčšou pravdepodobnost'ou nepraktizoval (Malamitsi-Puchner - Briana

2 Prechodové rituály predstavujú širokú škálu rôznorodých úkonov viažucich sa na prechody z jednej kategórie do druhej (van Gennep 1996, 11). Novorodenec $\mathrm{v}$ tradičných spoločnostiach je často vnímaný podobne ako cudzinec. Na to, aby bol akceptovaný spoločnost’ou, musí absolvovat' „predpísané“ rituály. Samotnému narodeniu samozrejme predchádzalo obdobie očakávania diet’at’a, s ktorým súviseli početné špecifické rituály (podrobnejšie cf. van Gennep 1996, 46-53; etnologické paralely cf. Ploss 1911, 25-48). 


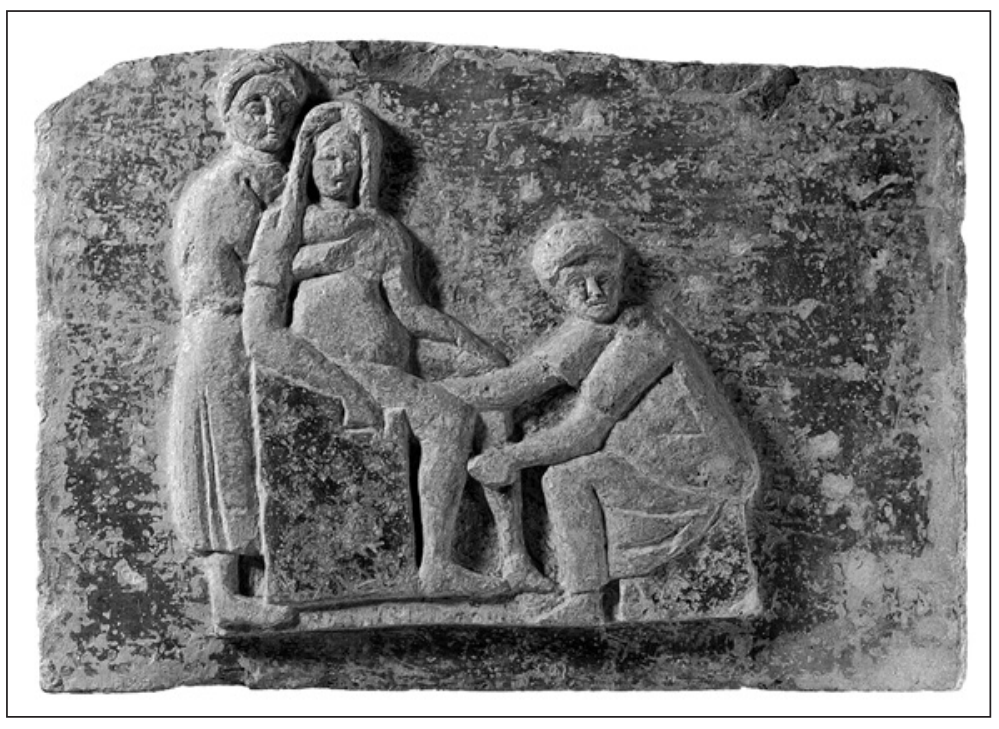

Obr. 4. Pôrodná babica kontroluje rodičku, scéna na reliéfu z hrobu - Scribonia Attica v Ostii, Itália, 2. stor. po Kr.

Fig. 4. Midwife controlling woman in labour, relief from tomb of Scribonia Attica in Ostia, 2nd century AD.
2017, 2-3), aj ked' mytológia (Dionýzos, Asklépios etc.) naznačuje aj iné možnosti, rovnako ako aj Plínius st. (23/24 - 79 po Kr.) a d’alší autori ho spomínajú. Cisársky rez však nepredstavoval rovnaký zákrok ako ho poznáme dnes, pristupovalo sa $\mathrm{k}$ nemu najmä $\mathrm{v}$ prípade úmrtia rodičky a nie je jasné, kol'ko živých detí sa týmto spôsobom mohlo narodit' a kto zákrok prevádzal. Podl'a rímskeho práva bolo z náboženských dôvodov zakázané pochovat' tehotnú ženu, pokial' z jej tela nebolo diet'a vybraté. Je možné, že i z tohto dôvodu sú nálezy hrobov žien s fetusmi „in utero “z priestoru Grécka a Rímskej ríše prakticky neznáme (Sameiro Barroso 2013, 75-80).

Už od dôb Hippokratových bola známa i embryotómia, t. j. postup odstránenia mŕtveho plodu z maternice jeho čiastočným rozdelením pomocou nástrojov za účelom záchrany života matky (Sameiro Barroso 2013, 81-85). Dva objavy plodov s perimortálnymi zásahmi na rímsko-britských lokalitách možno predstavujú práve tento prípad (Bonsall 2013, 81). Na lokalite Poundbury Camp v blízkosti Dorsetu sa našla skoro kompletná, disartikulovaná kostra donoseného diet’at’a, ktorého vek bol stanovený medzi 38 až 40 gestačných týždňov. Na kostiach boli stopy po rôznych zárezoch, ktoré mohli byt' spôsobené práve chirurgickými nástrojmi v súvislosti so snahou vybrat' diet’a z lona matky. Diet’a bolo uložené v drevenej rakvy, čo implikuje realizáciu regulárneho pohrebu (Caroll 2018, 54). Podobne na lokalite v Hambleden (Buckinghamshire) vo vile Yewden na kostre predčasne narodeného diet'at'a vo veku od 35 až 37 gestačných týždňov boli identifikované stopy po rezných ranách, ktoré by mohli taktiež indikovat', že diet’a bolo extrahované z matky chirurgicky (Mays et al. 2014). Inak archeologické doklady chirurgických zákrokov tohto druhu nie sú početné.

Obdobie bezprostredne po pôrode je súdobými písomnými prameňmi vel’mi málo popisované. Plutarchos (46 127 po Kr.) sa zmieňuje, že siedmy deň odpadá pahýl pupočnej šnúry, do tej doby je však novorodenec skôr rastlinou než zvierat'om (Plutarchos Quaest. Rom. 102, Mor. 288c). Novorodenecké obdobie (28 dní) je považované za najkritickejšie, čo sa adaptácie diet’at’a týka (Koštalová - Kovács 2005, 4) a bolo tomu tak i v antike. Už Aristoteles (Hist. Anim. VII, 588A) zaregistroval vysokú detskú mortalitu, pričom uvádza, že smrt’ ohrozovala predovšetkým deti počas prvého roku života a najviac ich umieralo hned’ v prvom týždni. Všeobecne sa dnes uvádza, že v prvom roku života zomrelo 20 - 40 \% detí (Golden 1990, 83; Caroll 2011, 102; Dasen 2013b, 2, viac k detskej mortalite Lewis 2007, 81-87).

Pravdepodobne $z$ dôvodu častých úmrtí novorodencov sa prechodový rituál oficiálneho prijatia diet'at'a do rodiny konal až niekol’ko dní po pôrode, preto je potrebné rozlišovat’ biologické „narodenie sa“ a sociálne „narodenie sa“ (Dasen 2011, 303; Parkin 2013, 45). V Attike sa v dome rodičov odohrávali obrady piaty, siedmy, desiaty a štrnásty deň po narodení v prípade zdravého diet'at'a (Garland 2013, 208-209). Ked' sa diet'a narodilo mŕtve alebo zomrelo krátko po pôrode, rituály sa nekonali. Postihnuté deti boli spravidla odložené (pozri nižšie). Pravdepodobne ako prvý sa konal obrad Amfidromia, ktorý mal charakter prijímacieho rituálu, v rámci ktorého bolo diet’a oficiálne prijaté rodinou a nadobudlo tým legálnu sociálnu identitu (Liston - Rotroff 2013, 76-77; Sommer - Sommer 2015, 56). Počas Amfidromii alebo siedmy deň po narodení sa schádza širšia rodina a obdarováva diet’a - tzv. opteria. Na desiaty deň diet'a počas obradu nazývaného aj dekaté obdržalo meno a bolo verejne uznané otcom za legitímneho potomka. V niektorých prameňoch je uvádzaná ešte slávnost’ tessarakostaion odohrávajúca sa štrnásty deň po pôrode, ktorá pravdepodobne ukončila „nečisté obdobie“ pre matku a diet’a (viac Garland 2013, 209). Presný popis rituálov sa v historických prameňoch líši, ich podstata je však zrejmá - postupné začleňovanie diet'at'a do širšieho spoločenstva.

Z obdobia rímskeho cisárstva pochádza najvýznamnejší písomný prameň týkajúci sa starovekého pôrodníctva, 
a to Soranova (98 - 138 po Kr.) príručka pre pôrodné babice (Gynaecia). V rámci štyroch kníh, z ktorých sa spis skladá, sa Soranus zaoberá menštruáciou, panenstvom, počatím, kontraceptívnymi a abortívnymi prostriedkami, pôrodom, starostlivost'ou o novorodencov, vrátane výberu dojky, taktiež gynekologickými ochoreniami a ich liečením. Soranus úspešne realizoval otočenia plodov v maternici v prípade nevhodných polôh a zaviedol pôrodnú stoličku pre rodiace ženy. Jeho návod hodnotenia vitálnosti novorodenca, ktoré pôrodné babice vykonávali ihned' po narodení diet'at'a, vykazuje určitú podobnost's dnes používanou stupnicou vitality - tzv. Apgar skóre (Karamanou et al. 2013, 227). Rímske rituály súvisiace s narodením a činnost’ami s ním spojenými rozoberá vo svojej publikácii pomerne podrobne Th. Köves Zulauf $(1990,3)$. Činnosti nasledujúce bezprostredne po pôrode rozdel’uje do siedmich fáz: 1 . odňatie z lona matky, 2. testovanie životaschopnosti, 3. oddelenie pupočnej šnúry, 4. umývanie, 5. zavinutie, 6. kladenie na lôžko, 7. prvé kŕmenie. Po oddelení pupočnej šnúry a prvom kúpeli sa diet’a definitívne oddelilo od matky, prestalo byt' súčast'ou jej tela (Caroll 2018, 63). V Ríme bol zásadnou udalost'ou v živote diet'at'a deň pomenovania - dies lustricus, ktorý sa, podobne ako Amfidromia, konal po prvom týždni od narodenia, konkrétne na ôsmy deň narodenia u dievčat a na deviaty deň narodenia u chlapcov, sprevádzaný rôznymi rituálmi (Caroll 2018, 63; Rawson 2003). Otázne zostáva, akú identitu malo diet'a do tohto dňa. Nebolo vnímané ako plnohodnotná l’udská bytost' alebo ako súčast' rodiny? Autori D. Sommer a M. Sommer $(2015,56)$ prirovnávajú status týchto nepomenovaných detí k potrateným fetusom. Znamená to však skutočne, že rodičia si nevytvorili puto k nepomenovanému diet'at'u počas ôsmich až desiatich dní a dokázali sa udržat' v akomsi režime emocionálneho odstupu, ako uvádzajú vyššie spomínaní autori?

\section{Percepcia novorodencov}

Ako výrazný faktor, ktorý sa mohol podiel’at’ na percepcii novorodencov a malých detí, sa javí predovšetkým ich fyzická resp. psychomotorická nezrelost' a závislost' na starostlivosti od dospelých. Odlišná percepcia mohla súvisiet' s ich vnímaním ako „cudzieho“, nového elementu v komunite (špeciálne z pohladu mužov - pozri Müller 1992, 12). Fyzická nezrelost’ novorodenca, či dojčat'a aj jeho špecifická telesná morfológia (obr. 5), nevyvážené telesné proporcie, konkrétne nevyrovnaný pomer vel'kosti hlavy a tela (najmä tesne po narodení zhruba do prvého roku), ${ }^{3}$ ktorý sa postupne vyrovnával, spôsobovali rôzne reakcie spoločnosti (Dasen 2008, 50).

S ich reflexiou sa stretávame napr. u Aristotela a Platóna v podobe prevažne negatívnych charakteristík, v ktorých sa novorodenci popisujú ako nedokonalé, slabé a škaredé stvorenia, často pripodobňované zvieratám alebo ženám

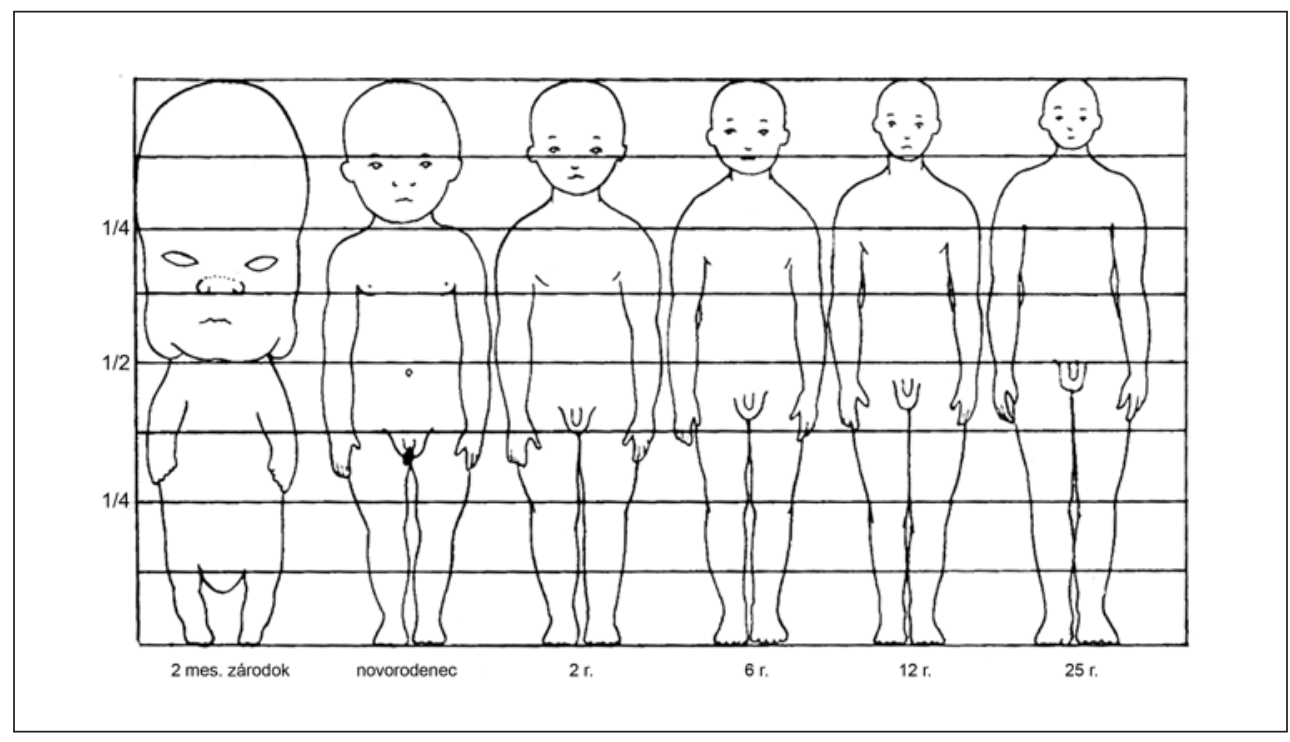

Obr. 5. Zmeny telesných proporcií diet'at'a (podl'a Klement et al. 1981, 27, obr. 152).

Fig. 5. Changes in proportions of the child's body (according Klement et al. 1981, 27, obr. 152).

3 Dížka hlavy novorodenca predstavuje zhruba 1/4 dížky celého tela, hlava dospelého len 1/8 (Koštalová-Kovács 2005, 4). 
vychádzajúc z podobnosti ich psychických a kognitívnych charakteristík (Platón, Leg. IV 710a 7-8; Aristoteles Phys. II 197b 7-8; Muggia 2004, 23). Aristoteles vo svojom diele (Gen. An. V 1.779a24; V 1.778b21; V 1.779a-80b; I 728a 17-18) uvádza, že malé deti zo začiatku spia viac než zvieratá, pretože sa narodili v ovel’a nedokonalejšej forme ako ostatné zvieratá a že ich horná čast’ tela je im prit’ažká, preto sa pohybujú ako štvornožci. Zároveň Platón (Platón Tht. 171e, Platón Resp IV 431c) pozoroval, že ženy a deti disponujú rovnakými vlastnost'ami ako nerozvážnost', nedostatok autonómie a emocionálna labilnost'. Tieto nedokonalé vlastnosti ich stavali do pozície podriadených v hierarchii rodinných aj komunitných vzt’ahov (Platón, Tht. 171e, Platón, Ústava, IV 431c; Muggia 2004, 24).

V diele Lukrétia (97 - 55 pred Kr.; De rerum natura) nájdeme už vecnejšiu charakteristiku novorodencov ako nemých a bezmocných stvorení vyžadujúcich si starostlivost' s primerane nízkym intelektom vo vzt’ahu k ich slabosti/ nemohúcnosti vyplývajúcej z ich krehkej stavby tela (Lucr., De rer, 3, 87-90; 3, 447-454). Podl’a V. Dasen (2008, 51-52; 2011, 293-294) sú často novorodenci a malé deti charakterizované v prameňoch vyslovene ako bytosti špeciálnej nižšej (inej) kategórie (zvieratá alebo trpaslíci, starí l’udia, či opilci), ktorá vykazuje fyzickú slabost', divokost', mentálnu nespôsobilost’ a nekontrolovatel’ný apetít. ${ }^{4}$ Táto „inakost”“ malých detí mohla byt’ jedným zo zásadných faktorov, ktoré mali vplyv aj na to, že neboli akceptované ako plnohodnotní členovia spoločnosti. Na získanie plnej sociálnej identity museli splnit’ určité spoločnost'ou stanovené normy. Pravdepodobnú interpretáciu percepcie novorodencov spoločnost'ou a zrejme do určitej miery aj rodinou, počas tohto prechodného obdobia (napr. pred pomenovaním a pod.), ked’ ešte neboli akceptovaní v rámci určitej sociálnej skupiny, uvádza napr. M. Melotti (2005, 203): „Existence had a meaning only inside the social group. Outside this social world he was an animal, a phantasm, a monster nearer to the "other" reality than to buman one (atimos)."

Pri posudzovaní písomných prameňov netreba zabúdat’ na to, že autormi týchto prameňov boli muži. Zastúpenie medzi antickými autormi, ktorí sa dotýkali „detských tém“ mali prevažne vzdelaní muži z vyšších sociálnych vrstiev. Ich názory boli výrazne ovplyvnené určitými subjektívnymi faktormi napr. záviseli od vnútorného filozofického presvedčenia autora, od primárneho účelu tvoreného textu, ciel’ovej skupiny a taktiež už spomínaného sociálneho postavenia a pod. Celkovo sa v týchto prameňoch venuje malá pozornost' najmenším det’om, pretože boli na okraji záujmu týchto autorov venujúcim sa najmä socio-politickým témam a je otázne, či možno uvedené hodnotenia aplikovat' na všetky deti, aj tie marginalizované - ako napr. deti otrokov, nelegitímne deti etc. (Backe-Dabmen 2006, 12; Caroll 2018, 3-4).

Ako teda antická spoločnost' vnímala smrt' detí? Pre mŕtvonarodené deti a smrt' novorodencov, príp. dojčiat neplatil oficiálny smútok, dokonca ani matka nesmela vyjadrovat' smútok (plač) na verejnosti. ${ }^{5}$ Plutarchos v životopise Numovom (Bioi paralléloi XII, 2) uvádza, že oficiálne mohli smútit' rodičia až za diet’at'om, ktoré malo viac ako tri roky. Známa je tiež pasáž Plutarchovho listu žene po smrti ich dvojročnej dcéry: „Skutočnost’ v týchto veciach možno vidiet' skôr v dávnych zvykoch a zákonoch našich predkov; pretože naši l’udia nevykonávajú úlitby tým det'om, ktoré zomreli ako dojčatá, ani d’alšie obrady, ktoré žijúci konajú pre mŕtvych, pretože tieto deti nemajú podiel na zemi a pozemských veciach; ani nezostávajú v miestach, kde sa koná pohreb, v hroboch, alebo pri vystavení tela ...... Pretože zákony nám zakazujú trúchlit’ nad dojčatami, považujúc za bezbožnost' trúchlit' za tými, ktorí odišli k úl’ave a tiež na miesto, ktoré je lepšie a viac božské.” (Plutarchos, Mor. - Consolatio ad Uxorem, 612 B). Aj Cicero v Tuskulských rozhovoroch komentuje smrt' detí tak, že pozostalí by mali niest' stratu vyrovnane, pokial' diet'a zomrelo v kolíske, tak nie je vhodné ho oplakávat' (Cic., Tusc. I, 39; Caroll 2011, 100). Pravdepodobne toto ustanovenie súviselo práve s vysokou detskou mortalitou v tomto období. Analogickú situáciu uvádza aj K. E. Müller (1992, 12) na základe štúdia tradičných kultúr.

Z vyššie uvedeného je zrejmé, že prejavovanie smútku na verejnosti bolo regulované. I tieto pramene však nepriamo vypovedajú o t’ažkom prežívaní straty diet’at'a a že prirodzená rodičovská láska existovala, i ked' bola podriadená spoločenským normám, ktoré sa navonok rešpektovali. Príklady hlbokého žial’u rodičov v antickom Grécku nad stratou sladkých potomkov uvádza M. Golden (1988, 153). Aj Plutarchov list, okrem vyššie spomínanej pasáže, zretel'ne popisuje starostlivost' a náklonnost', ktorú so svojou ženou prechovávali voči svojím det'om. Aj ked' rímski

\footnotetext{
4 V. Dasen sa snažila nájst' v gréckej ikonografii paralely k tomuto ponímaniu detí (cf. Dasen 2008).

5 Numa stanovil oficiálny smútok až od určitého veku, napr. na smrt' diet'at'a mladšieho ako tri roky sa vôbec nevzt'ahovalo právo oficiálneho smútku. V prípade smrti staršieho diet’at'a oficiálny smútok nesmel trvat' vyšší počet mesiacov ako počet rokov, ktoré diet’a žilo (max. 10 mesiacov) a zároveň 10 mesiacov bola maximálna dížka oficiálneho smútku bez ohl’adu na vek.
} 
autori uvádzajú, že materská láska sa prejavovala výraznejšie v porovnaní s otcovskou (Stearns 2011, 37), v písomných prameňoch z rímskeho obdobia sú aj zmienky o prejavoch lásky mužov voči vlastným det’om a o silnom smútku po ich náhlej strate. Napr. Lukrétius ( $97-55$ pred Kr.) sa bojí straty „pôvabných detí, ktoré sa náhlia uchmatnút’ si prvý bozk pri pozdrave a rozorvú srdce nevýslovnou radost'ou" (De rer. nat. 3.894-8, cf. 4.1233-56; Golden 2013, 250). M. C. Fronto (100 - 175 po Kr.) sa st’ažuje v liste z roku 165 po Kr. cisárovi Marcovi Auréliovi, že jeho pät' detí zomrelo po sebe, tak že mu nezostalo ani jedno pre útechu (Dasen 2013b, 2). Ausonius (310 - 395 po Kr., Parentalia 10) píše: „Nenechám t’a neoplakaného, syn môj, ani neodopriem nárek nad tvojou pamiatkou, tebe, moje prvorodené diet’a a môj menovec. V čase, ked’ si sa začal učit' prvé detské slová, plný darov prírody, musíme žialit' nad tvojou smrt'ou. Ležís na hrudi svojho starého otca, s ktorým sa delíš o spoločný hrob, aby si nemusel byt' osamelý“ (Hope 2017, 184). Ďalšie popisy nájdeme napr. u Senecu, Quintiliána, Plínia ml. a iných autorov (Backe-Dabmen 2006, 12-47; Hope 2007, 184; Parkin 2013, 43; Golden 2013).

Skutočnú stratu a smútok rodičov vyjadrujú aj epigrafické pamiatky (náhrobné kamene, stély apod.) i napriek nepomeru, teda nízkemu počtu týchto pamiatok v pomere k vysokej detskej úmrtnosti. Emócie súvisiace so stratou potomstva sú reflektované rovnako aj na epitafoch a taktiež v literárnych dielach, ako aj v mytológii, i ked’ skôr ojedinele (Hope 2007, 183; Garland 2013, 221; Sommer-Sommer 2015, 53).

\section{1. Praktikovanie odloženia novorodencov a infanticídy}

V antických prameňoch sa pomerne často stretávame s prípadmi odloženia ešte živého diet’at'a. ${ }^{6}$ Predpokladá sa, že táto úloha často pripadla pôrodnej babici (podobne ako zbavit' sa telička v prípade mŕtvonarodených detí alebo úmrtia novorodenca čoskoro po pôrode; Liston - Rotroff 2013, 77).7 Deti mohli byt' opustené, resp. pohodené z rôznych dôvodov - postihnutie, nelegitímnost' a ekonomická situácia, napr. regulácia vel'kosti rodiny kvôli chudobe, u bohatých snaha netrieštit' rodinný majetok, deti otrokýň etc. (Lindenlauf 2001, 91; Evans Grubbs 2013, 84-92). Najčastejšie sú zmienky o odložení detí u vdov a rozvedených žien, teda detí de facto bez otca. Prvou známou referenciou v antickom svete je pasáž v Gortýnskom zákonníku (okolo 450 pred Kr.). Na druhej strane šanca, že sa odloženého diet'at'a niekto ujme, evidentne existovala, pretože očakávanie spoločnosti v súvislosti so zabezpečením dediča vyvíjalo značný tlak na ženy po vstupe do manželstva. Obavy mužov z podstrčeného potomka (ktorým mohli byt' práve expositi) sa zrkadlí v súdobých dramatických hrách, kde sa téma „senzačného” odhalenia identity pôvodne opusteného diet'at'a pravidelne objavuje, napr. Sofoklov Oidipus král' (Evans Grubbs 2013, 84-87).

Výrazne negatívne konotácie má z dnešného pohladu hlavne infanticída. Pod pojmom infanticída rozumieme usmrcovanie nechcených novorodencov a dojčiat (Krausse 1998, 328; Mays 2000, 180). ${ }^{8}$ Prerušenie nežiaduceho tehotenstva malo pre ženu ešte väčšie zdravotné riziká ako samotné donosenie plodu, ktorý bol potom následne odložený či zabitý (viac k potratom Dasen 2013a, 25-26). Často išlo zrejme o krajné riešenie, ktoré ostro kontrastovalo s už zmieňovanými ochrannými opatreniami u želaných potomkov. Názory bádatel’ov sa v otázke, do akej miery je možné praktikovaním „odkladania“ detí a infanticídou vysvetlit' deficit pozostatkov najmenších detí na pohrebiskách, rôznia (Mays 1993, 887; Krausse 1998; Caroll 2011, 109). Od donedávna zauživanej interpretácie týkajúcej sa výrazného preferovania usmrcovania novorodencov ženského pohlavia sa dnes už postupne ustupuje (Scott 1997, 68-69; Evans Grubbs 2013, 91-93). Viacerí autori odmietajú tvrdenie, že by infanticída bola masovo praktikovanou normou (Pearce 2001, 129; Grabam 2010). Samotné identifikovanie infanticídy v archeologických kontextoch je problematické a t’ažko doložitel'né (Scott 1999, 66). Deti mohli byt' otrávené, pochované zaživa, udusené, uškrtené, vyhladované, utopené, nechané napospas divým zvieratám (Ploss 1911, 52-53, 163, 165) alebo zbavené života iným spôsobom, ktorý nezanechal stopy na antropologickom materiáli. Pre posudzovanie a interpretáciu infanticídy musíme v prvom rade porozumiet’ špecifickým kultúrno-sociálnym pomerom danej komunity. Zaujímavý názor v tomto kontexte ponúka M. Golden $(1990,89)$, podl’a ktorého práve tieto praktiky môžu byt' paradoxne dokladom lásky a starostlivos-

\footnotetext{
6 Odložené deti boli označované ako expositi, z lat. expositio; v iných jazykoch termínmi: „abandonment", „exposure“, „Aufsetzung“.

7 Čo sa potom dialo s telami neželaných detí popisuje napr. J. Evans Grubbs (telá hodené do studní, kanálov či riek, rozvlečené psami po uliciach, používané pri pitvách, alebo pre magické účely etc.; Evans Grubbs 2013, 100).

8 Usmrcovanie starších detí sa označuje termínom pedicída.
} 
ti o staršie potomstvo. Infanticída bola v Rímskej ríši z právneho hladiska povolená až do roku 374 po Kr. Určité legislatívne snahy o ochranu novorodencov však začínajú za Trajána (Institutio alimentaria v roku 99 po Kr. - finančná podpora det'om z chudobných rodín) a Konštantína po prijatí krest’anstva v roku 313 po Kr. Krest’anstvo potom znamenalo zásadnú zmenu v právnom prístupe k odkladaniu detí a infanticíde (Evans Grubbs 2013, 99).

Bezpochyby negatívne vnímala spoločnost' deti s postihnutím, znetvorené deti neboli považované za l'udských novorodencov. Usmrcovanie takýchto jedincov má v antike dlhú tradíciu. Napr. Plutarchos popisuje v životopise Lykurga (16.1-2) situáciu v Sparte, kde boli neduživé a postihnuté deti na základe rozhodnutia najstarších členov rodu z otcovej strany ponechané/poslané na miesto tzv. Apothetai/e $e^{9}$, teda do jamy/priepasti na úpätí hory Taygetos (Ploss 1911, 161-162; Krausse 1998, 329; Cambiano 2005, 78; Beilke-Voigt 2007, 179). ${ }^{10}$ V Ríme v období republiky boli postihnuté deti na základe rozhodnutia senátu vychádzajúc z inštrukcií etruských kňazov otrávené (Krausse 1998, 329). V niektorých prípadoch boli na smrt' „odsúdení“ aj z nášho pohl’adu celkom zdraví jedinci, ktorí z rôznych dôvodov nespĺňali vtedajšie kritériá životaschopného a zdravého diet’at’a (Krausse 2002, 179). Napr. filozof Seneca zmieňuje likvidáciu „zlovestných potomkov a detí neduživých a znetvorených“ (De Ira 1.15.2; Evans Grubbs 2013, 88).

Napriek všeobecnej nevôli voči postihnutým det'om, existujú aj doklady, kedy aj postihnuté deti boli vychované do dospelosti, predovšetkým v král’ovských rodinách. ${ }^{11}$ Niektoré defekty sa totiž nemuseli prejavit' hned' po narodení. Postihnuté deti mohli byt' využívané v cirkusových predstaveniach alebo ako žobráci budiaci svojím zjavom súcit okoloidúcich. Od dôb Augusta naviac evidujeme snahu o zvýšenie pôrodnosti u rímskych občanov a zákonné postihy pre bezdetné rodiny (čo je známe už zo Sparty). To tiež mohlo viest’ k vychovávaniu hendikepovaných detí (Golden 1988, 153; Evans Grubbs 2013, 88).

\section{Pohrebný rítus}

Percepcia najmenších detí, teda najmä novorodencov a detí do jedného roka, je reflektovaná aj v normách súvisiacich s pohrebným rítom. V dielach antických autorov však skoro úplne chýbajú informácie týkajúce sa zaobchádzania s pozostatkami fetusov, resp. predčasne narodených detí. Viac informácií sa vzt’ahuje k novorodencom, resp. k starším det’om. Podstatnú úlohu pri kreovaní rituálnych predpisov v súvislosti s pochovávaním najmenších detí zrejme zohralo vedomie vysokej perinatálnej mortality.

Archeologické doklady pozostatkov fetusov a predčasne narodených detí nie sú vel'mi početné, ale v posledných desat'ročiach ich počet narastá a identifikované sú v rôznych kontextoch. Niektorí autori uvádzajú, že pohodenie detí bolo v Grécku bežné obzvlášt' v období pred 8. stor. pred Kr., podobne ako tomu bolo u dospelých jedincov nižších spoločenských vrstiev (Lindenlauf 2001, 95). V tomto období sú detské pozostatky prevažne známe zo sídlisk. Na začiatku 7. stor. pred Kr. sa začínajú kostrové hroby detí objavovat' vo väčšej miere aj na pohrebiskách, čo indikuje vývoj statusu detí v rámci komunity. Táto zmena sa dáva do súvisu s procesom vzniku gréckych poleis. Napr. v Aténach od konca 8. do konca 5. stor. pred Kr. počet detských hrobov na pohrebiskách výrazne narástol (Caroll 2018, 20). Malým det’om býva často vyhradený enchytrismos - typ pohrebu v nádobe (regionálne špecifické typy nádob - amfory, hydrie, stamnosy, pitosy a pod.) rozšírený na komunálnych pohrebiskách v celom Grécku i v oblastiach kolonizovaných Grékmi v južnej Itálii, na Sicílii alebo v južnom Francúzsku (Marseille).

Najväčšie nálezisko pozostatkov najmenších detí na svete predstavuje lokalita Kylindra v Astypalaii na Dodekanézoch (Clement-Hillson - Michalaki-Kolia 2008), kde bolo pochovaných viac ako 2770 fetusov a novorodencov práve v keramických nádobách (obr. O). Pohrebisko bolo situované na okraji antického mesta, mimo regulárneho pohrebiska a pochovávanie tu prebiehalo od geometrického obdobia kontinuálne do doby rímskej. Doložené sú fetusy od 24. gestačného týždňa až po pár jedincov do troch rokov, ale väčšinu predstavujú donosení novorodenci. Najčastejšie boli deti umiestené v nádobe hlavou otočenou smerom k ústiu nádoby, ale približne v 10 \% prípadov boli otočené opačne. To by mohlo indikovat' ich polohu pri pôrode - koncom panvovým, ktorý predstavuje aj väčšie riziko úmrtia (v súčasnej západnej spoločnosti sa táto poloha vyskytuje pri cca $4 \%$ pôrodov). Nálezy dvoch jedincov v nádobe by

\footnotetext{
9 Z gréckeho apothesis a ekethesis, t. j. odloženie.

10 Avšak pri citovaní tejto správy od Plutarcha si treba uvedomit’ časový odstup medzi životom Lykurga a popisovaním tejto situácie Plutarchom.

11 Napr. spartský král Agesilaus alebo rímsky císar Klaudius (Evans Grubbs 2013, 88).
} 


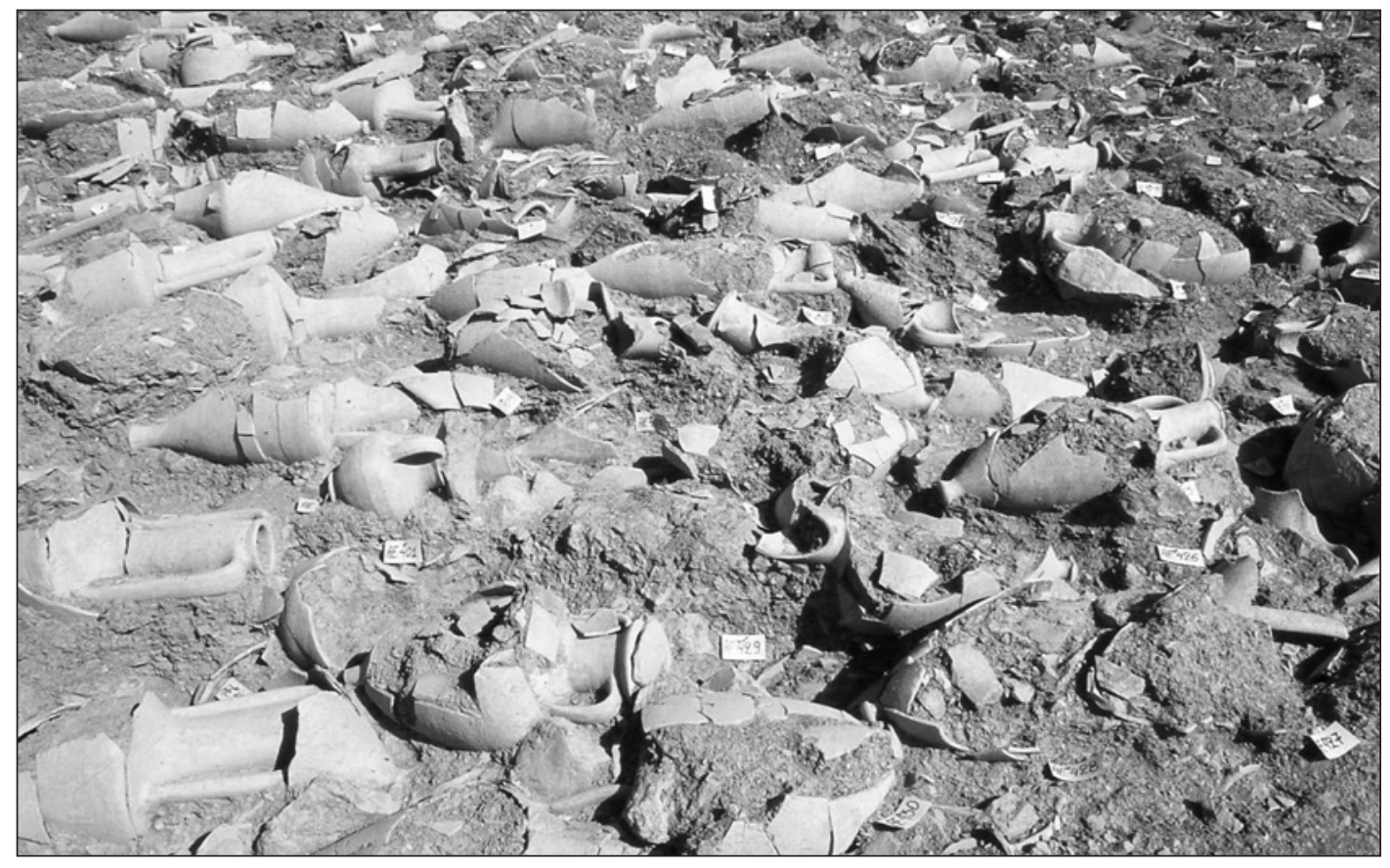

Obr. 6. Enchytrismoi na pohrebisku Kylindra na ostrove Astypalaia (podl'a Clement-Hillson - Michalaki-Kolia 2008).

Fig. 6. Enchytrismoi on Kylindra cemetery on island Astypalaia (according Clement-Hillson-Michalaki-Kolia 2008).

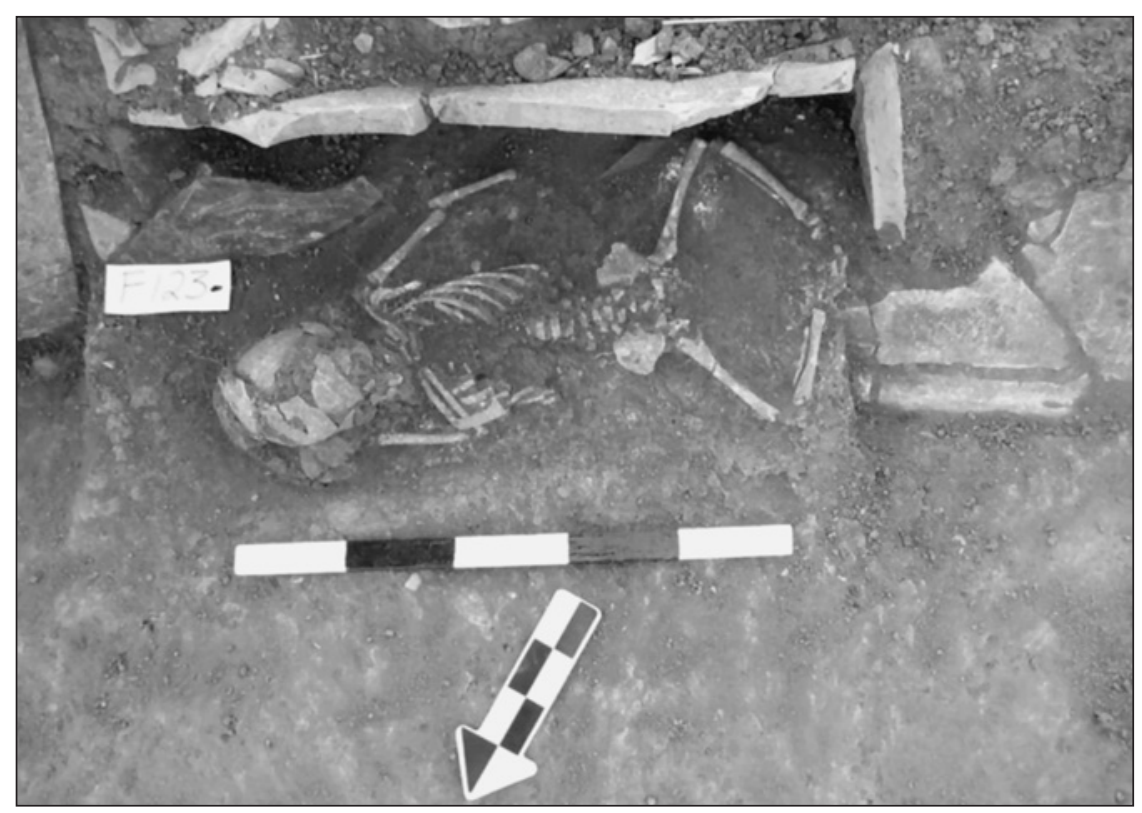

Obr. 7. Pohreb dojčat’a alla capuccina po otvorení, Vagnari, Itália (podl'a Caroll 2018, 188, Fig. 7.4).

Fig. 7. Infant burial alla capuccina after opening, Vagnari, Italy (according Caroll 2018, 188, Fig. 7.4). 
mohli patrit' dvojčatám. Percentuálne zastúpenie týchto prípadov predstavuje necelé $2 \%$, čo zodpovedá aj dnešným štatistikám. Vymedzenie priestoru pre pochovávanie najmenších detí svedčí o ich odlišnom vnímaní spoločnost’ou. Podl’a autorov mohlo toto miesto slúžit' okrem pochovávania novorodencov, aj ako kultové miesto zasvätené bohyniam Artemis Locheiy a Eileithyie, ochrankyniam pri pôrode (Clement - Hillson - Michalaki-Kolia 2008, 21).

Iným príkladom zaobchádzania s detskými pozostatkami sú nálezy kostí cca 449 detí, vrátane fetusov a novorodencov nájdených v studni v blízkosti aténskej agory (Liston - Rotroff 2013, 63). Pôvodne bol vysoký počet pozostatkov interpretovaný ako doklad masovej infanticídy alebo morovej epidémie, či hladomoru, ale ukázalo sa, že pozostatky detí boli ukladané do nepoužívanej studne v priebehu asi 15 rokov, zrejme medzi rokmi 165 - 150 pred Kr. Ako prílohy sa tu našli aj nádobky s výlevkou, ktoré pôvodne zrejme slúžili na kŕmenie detí a d’alšie milodary, tiež otvorené misovité keramické tvary, v ktorých mohli byt' telá detí prinesené vychádzajúc z popisu potrebného vybavenia u Sorana pri pôrode, ktorý podobné tvary v tomto kontexte spomína (Liston - Rotroff 2013, 66-67; Caroll 2018, 25). Pri podrobnejšej paleopatologickej analýze sa d’alej zistilo, že jedna tretina jedincov zomrela na novorodeneckú meningitídu (na základe analýzy lebečných kostî). Niektorí jedinci však disponovali defektmi, napr. rázštepom podnebia a i. (Liston - Rotroff 2013, 63). Väčšina detí z aténskej studne teda zomrela z prirodzených príčin, malá čast' z nich však mohla byt' zabitá či pohodená do opustenej studne kvôli vrodeným vadám, prípadne sem mohli byt' premiestnené telá mŕtvych expositi, ktorých sa nikto neujal (Liston - Rotroff 2013, 76).

Podobne v Mesénii v studni na agore sa objavili kosti viac ako 260 malých detí (plodov, predčasne narodených a mítvonarodených detí, novorodencov) a psov spolu s keramickými fragmentami (Bourbu - Themelis 2010). Podla interpretácie Ch. Bourbu a P. Themelisa boli deti pravdepodobne pôvodne pochované v nádobách na inom mieste a ich pozostatky boli do studne prenesené dodatočne a následne sa studňa začala používat' na „pochovávanie“ detí, ktoré zomreli pri pôrode (podla niektorých autorov sa táto hypotéza nedá dokázat', cf. Caroll 2018, 25). Pozostatky detí z aténskej studne taktiež sprevádzalo cca 130 psov, ktorí sú, okrem iného, považovaní za obetné zvieratá majúce väzbu aj na ochranné božstvá zabezpečujúce bezproblémovost' pôrodu a rituálnu očistu a pod. (Eileithyia, Artemis Orthia a pod., Bourbu - Themelis 2010, 116; Caroll 2018, 25).

Vývoj zaobchádzania s pozostatkami detí od 7. stor. až po 2. stor. pred Kr. je možné sledovat' na pohrebiskách v Abdére (Kallintżi - Papaikonomou 2010,136). Najviac detských hrobov pochádzalo z archaického obdobia (vrátane fetusov od 20. gestačného týždňa), v priebehu helenistického obdobia zastúpenie detí na pohrebiskách výrazne kleslo a preto je nutné uvažovat' o inom spôsobe zaobchádzania s pozostatkami. Na základe analýzy pohrebných areálov sa zdá, že nárok na milodary mali až deti, ktorým sa začali prerezávat’ zuby a začali prijímat’ aj tuhú stravu t. j. okolo šiestich mesiacov až jedného roku (Dasen 2013, 33).

Ako sa k pochovávaniu tých najmenších pristupovalo v Rímskej ríši? U Plínia st. (Nat. Hist. VII, 72) sa ako jedno zo zásadných zlomových období s ohl’adom na vol’bu väčšinového pohrebného rítu - kremácie - javí prerezanie prvého zubu vo veku šiestich mesiacov. Aj Juvenalis (60 - 127 po Kr.) vo svojich Satirách (XV, 135) uvádza, že najmenšie deti neboli spalované, konkrétny vek však neudáva. Vo všeobecnosti možno skonštatovat', že mladšie deti boli pochovávané kostrovo, ako uvádza Plínius st., ale nájdeme aj prípad takto pochovaného dvojročného diet’at’a z Pompejí. Hoci začiatok erupcie dočasného chrupu môže variovat' od 4 do 12 mesiacov, rigidná univerzálnost' Plíniovho výroku je diskutabilná, ako ukazujú i d’alšie nálezy, napr. spálené pozostatky novorodencov z niekol'kých lokalít v Galii, napr. z pohrebiska Saint-Lambert, Argenton nebo vo Martigny (Blaizot et al. 2003, 52; Caroll 2011, 105-106; Caroll 2018, 182).

Čo sa týka územia samotnej Itálie, najmenším det’om na rímskych pohrebiskách od 1. stor. pred Kr. po rok 300 po Kr. venovala pozornost' M. Caroll (2011). Pozostatky detí starších ako jeden rok sú bežne na pohrebiskách doložené, avšak deti mladšie ako 12 mesiacov sa na nich vyskytujú len sporadicky $(2-10 \%$, výnimočne $30 \%$ - pohrebisko Porta Marina Sud, Velia) a pozostatky fetusov chýbajú. Dojčatá (vrátane novorodencov) mohli byt' pochované v drevených rakvách, alebo v cistových hroboch zo strešných škridiel či kamenných platní (tzv. alla cappuccina - obr. 7). Boli taktiež umiestnené $\mathrm{v}$ rodinných hrobkách. V hroboch malých detí sa nachádzajú ako prílohy nádobky slúžiace na kŕmenie, ochranné amulety, d’alej mince, lampy, keramické nádoby, teda predmety, ktoré sa bežne vyskytujú aj v hroboch dospelých, cenné predmety, napr. zlaté šperky však mali až staršie deti ako jeden rok (Caroll 2011, 108).

Neskoroantický autor Fulgentius (5./6. stor. po Kr.) píše, že deti, ktoré sa nedožili 40 dní, boli pochované v tzzv. suggrundaria-ch. Bližšie vysvetlenie tohto termínu podáva R. Fellman $(1993,13)$, ktorý predpokladá, že tento pojem 
súvisí so slovom subgrunda, ktoré nachádzame napr. u Varra (De re rustica III, 3, 442) a Plínia st. (Nat. Hist. XXV, 160) $\mathrm{v}$ zmysle striešky, krytu. Na základe výkladu slova suggrunda filológmi vznikla interpretácia, že ide o hroby detí uložené pod prečnievajúcou strechou domu (Gjerstad 1954, 291). Ako príklady hrobov zodpovedajúce termínu suggrundaria sa v súčasnosti považujú najmä nálezy detských pozostatkov z kontextov mimo pohrebísk. Napriek tomu, že podl’a rímskeho práva nesmeli byt' telá pochovávané intra muros, pozostatky malých detí sa nachádzajú pomenej v mestách v zmysle väčších aglomerácií, častejšie však vo vidieckom prostredí, vilách či v dielňach, a to predovšetkým v Galii či Británii (Scott 1999, 114; Pearce 2001, 127; Baills-Barré 2010). V Itálii sa objavujú hroby malých detí mimo pohrebísk (opustená villa v Lugnane, pohreby pod podlahou a pozdĺž múrov v Loppio-S. Andrea, Mezzocorona) vo väčšej miere až v neskororímskom období (Caroll 2011, 110). V Británii počet perinatálnych jedincov nachádzajúcich sa mimo pohrebísk a dojčiat stúpa vo 4. stor. po Kr. (Struck 1993, 317; Scott 1999, 114). Pohreby detí v nádobách, na sídliskách a v obydliach majú dlhú tradíciu v celom Stredomorí, podl’a M. Caroll $(2011,111)$ môže íst' o jej znovuobnovenie po kolapse rímskej spoločnosti. K teórii „vzkriesenia” pôvodnej domácej tradície pre oblast’ Británie sa prikláňa napr. i M. Struck (1993, 317), ktorá analyzovala vyše 700 detských hrobov, vrátane cca 200 hrobov malých detí do dvoch rokov. Na druhej strane sa narastajúca početnost' prítomnosti perinatálnych jedincov a dojčiat na pohrebiskách dáva do súvisu s prijatím krest’anstva (Scott 1997, 114; Pearce 2001, 128).

Vyšší počet pozostatkov detí v perinatálnom veku nachádzané mimo pohrebísk bol v minulosti často interpretovaný ako dôsledok praktikovania infanticídy (Mays 1993; Mays - Eyers 2011). Takýmto je napr. nález takmer stovky detí, ktoré sa našli v roku 1988 v kanáli pod neskororímskymi kúpel’mi v Ashkelone v Izraeli (Smith - Kabila 1992). Viaceré nálezy z neskororímských britských lokalít boli interpretované ako doklady likvidácie nechcených potomkov (Mays 1993). K novšie publikovaným patria pozostatky 97 dojčiat z výskumu rímskej villy Yewden v Hambledene (Mays - Eyers 2011). Ked’že medzi perinatálnymi jedincami z Ashkelonu dominovali na základe určenia pohlavia chlapci, nálezy pozostatkov boli interpretované ako nechcené deti prostitútiek pracujúcich v kúpel’och, ktoré mali záujem vychovávat' hlavne dcéry, ktoré by mohli pokračovat' v ich remesle. Pozostatky detí však boli na mieste deponované až po zániku kúpel’ov. Podobne bola vysvetl’ovaná aj situácia v Hambleden. Tieto práce boli podrobené kritike zo strany viacerých bádatel’ov, ktorí výsledky reinterpretovali ako dôsledok prirodzenej perinatálnej úmrtnosti (Scott 1999, 68; Bonsall 2013; Graham 2016; Gowland 2016, 311; Caroll 2018, 172-174).

Hroby detí do jedného roka sa v galorímskom prostredí nachádzajú na pomedzí dvoch priestorov, napr. na okraji ulice, na hranici mesta, pri hradbách, pri stenách budov, v priekopách oddelujúcich pars rustica od pars urbana u rímskych víl a pod., čo demonštruje liminálny status týchto detí (Pearce 2001, 136; Moore 2009, 48; Dasen 2011, 305-307). Na príklade detských hrobov pod podlahou zaniknutej hrnčiarskej dielne v Sallèles d'Aude v Galii z 1. a 2. stor. po Kr. je vidiet', že ide skôr o prejav rituálneho správania než o nedbalé pohodenie (obr. 8). Novorodenci tu boli uložení v skrčenej polohe bez milodarov, škridla alebo jej fragment slúžili zrejme k označeniu hrobu než k jeho ochrane. Dojčatá do troch mesiacov boli uložené vo väčšej jame vo vol’nejšej skrčenej polohe, vychádzajúc z polohy rúk a nôh niektorých z nich sa uvažuje o tom, že mohli byt' zavinuté. Hrob mali tiež zakrytý škridlou. Najstaršie diet’a, 6-9 mesiacov, malo konštrukčne zložitejší, tehlami ohraničený hrob, zakrytý dvomi tegulami, ktorý obsahoval sadu troch keramických predmetov (Duday - Laubenheimer - Tillier 1995; Baills-Barré 2016). Tieto nálezové situácie naznačujú, že deti boli pochované v závislosti od dosiahnutej úrovne spoločenskej integrácie, ktorá bola podmienená do značnej miery vekom. Podobné zaobchádzanie s pozostatkami detí možno pozorovat' i na d’alších juhofrancúzskych lokalitách, kde sa v hroboch detí od veku cca šiestich mesiacov, čo zodpovedá zhruba začiatku prerezávania sa zubov, začínajú pravidelnejšie objavovat' prílohy. Artefakty sprevádzajúce deti sa často vzt'ahujú k ženskej sfére, preto neindikujú nutne pohlavie detí, ale skôr odrážajú starostlivost’ žien (Dasen 2009, 210).

A. Moore $(2009,48)$ sa domnieva, že pohreby detí v sídliskovom kontexte nie sú ,the random disposal of the unwanted or marginalised, but the result of careful choices and decisions relating to concepts associated with the physical and spiritual worlds, the infant was inherently ambiguous but was also, in certain senses, a being of power". Fakt, že deti mohli byt' pochovávané v blízkosti obydlí podl’a V. Dasen $(2013,34)$ indikuje, že na rozdiel od iných kultúr, v starovekom Grécku a Ríme neboli deti zosnulé pred rituálom pomenovania, považované za nečisté a nepremieňali sa na zlých duchov, aby škodili žijúcim.

Na základe súčasného stavu výskumu možno sumarizovat', že deficit najmenších detí na pohrebiskách a ich prítomnost' na sídliskách nevypovedá o ich podradnom postavení a l'ahostajnosti rodičov k smrti detí, ale svedčí skôr o zvláštnom statuse, ktorý sa prejavuje špecifickým pohrebným rítom. 


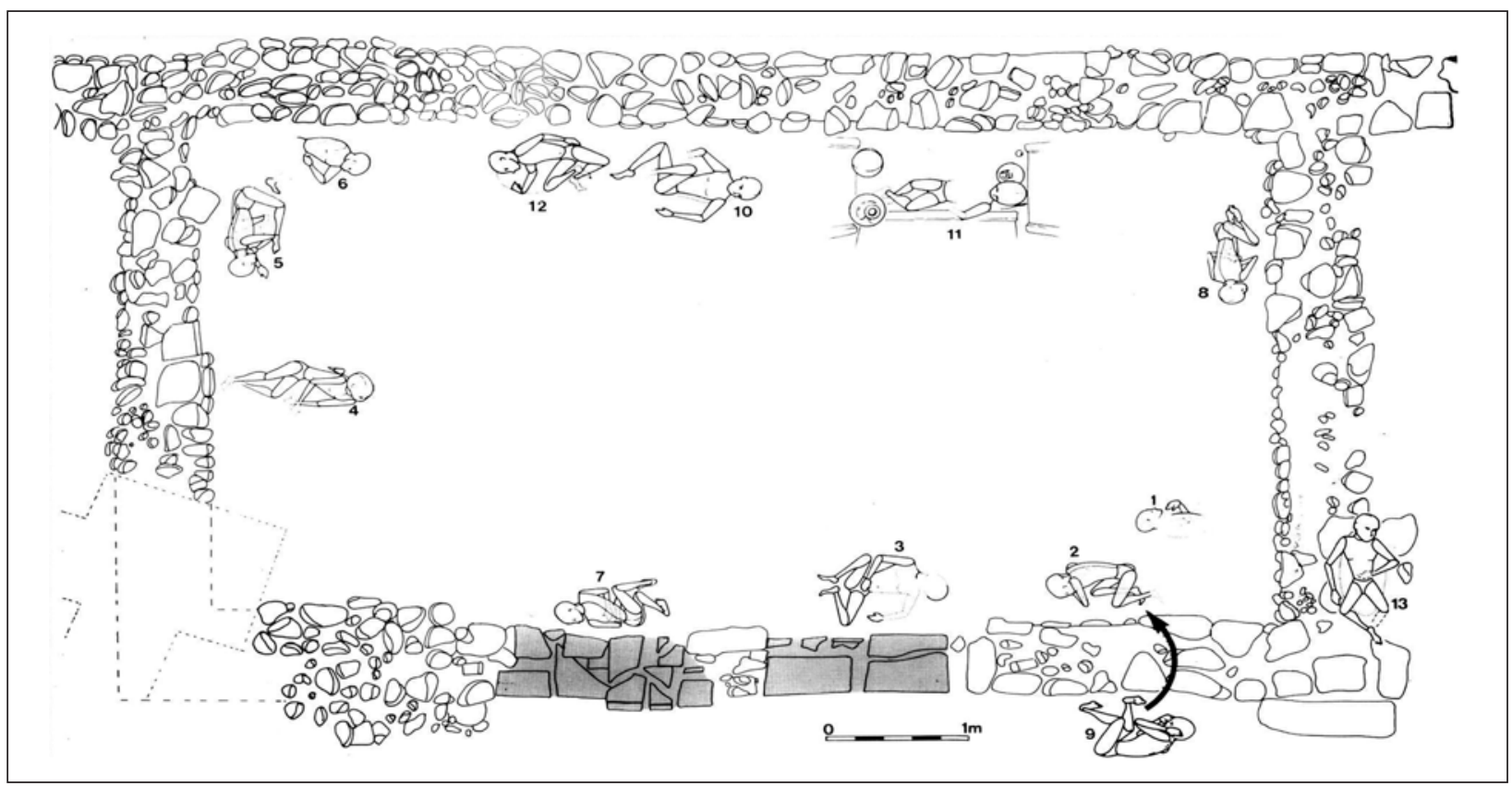

Obr. 8. Plán hrnčiarskej dielne s vyznačenými hrobmi detí, Sallèles d’Aude, Francúzsko (podl'a Duday - Laubenheimer - Tillier 1995, 98, Fig. 66).

Fig. 8. Plan of ceramic workshop with infant burials indicated, Sallèles d'Aude, France (according Duday - Laubenheimer - Tillier 1995, 98, Fig. 66).

\section{Diskusia a záver}

Pluralita názorov na percepciu fetusov a malých detí u antických autorov je daná charakterom písomných prameňov, ktoré nám neposkytujú ucelený obraz, ale skôr mozaiku rôznych hl'adísk a perspektív podl'a osobnosti pisatel'a, naviac väčšinou mužského pohlavia a zároveň pochádzajú zo širšieho chronologického a geografického rámca.

Záujem o najmenšie deti bol dlhodobo vo vedeckej literatúre marginalizovaný. V odbornej literatúre vychádzajúcej z antických prameňov sú deti a detstvo, v kontexte článku aj práve najmenšie deti, v minulosti prezentované prevažne negatívne. Úvahy učencov (napr. Platón, Aristoteles) o det’och ako bytostiach nedokonalých a prirovnávaných napr. ku zvieratám viedla k náhl’adu na ich podradné postavenie v staroveku, oficiálne zákazy trúchlenia nad smrt'ou detí boli potom interpretované ako nedostatok rodičovskej lásky odôvodňované vysokou detskou mortalitou (Golden 1988; Rawson 2003; Caroll 2011; 2018; Sommer - Sommer 2015 a d’alšî). V posledných rokoch je badatel’né prehodnocovanie tohto dominantne negatívneho pohl’adu na deti (Caroll $2018 \mathrm{~s}$ d'alšou literatúrou), i ked' aj v novšej literatúre sa tieto názory stále objavujú, resp. sa tendenčne preberajú. Súvisí to samozrejme s viacerými aspektami, ale predovšetkým je to dané vplyvom nášho súčasného nazerania napr. na praktikovanie odloženia detí alebo infanticídy bez zváženia širšieho kontextu.

Pri riešení tejto problematiky je nutné rozlišovat' dve roviny percepcie, z ktorej prvá predstavuje verejnú sféru sledujúcu oficiálne záujmy štátu, teda rovinu vzt’ahov spoločnosti k det’om, ktorá je reflektovaná vo filozofickej, právnej resp. medicínskej spisbe. Druhá rovina, ktorú reprezentujú vzt’ahy medzi rodičmi a det'mi, sa prejavuje najmä v súkromnej korešpondencii, v literatúre a pod. (napr. Cicero, Lukrétius, Fronto, Ausonius). Všeobecne boli deti brané ako pokračovatelia rodu, ich úlohou bolo sa postarat' o rodičov v starobe, u nižších vrstiev bol očakávaný ekonomický prínos už počas detstva. Pre prežitie diet'at'a bolo zásadné nielen biologické narodenie sa, ale predovšetkým jeho sociálne narodenie sa - začlenenie do spoločnosti (Amfidrómia a Dekaté v Grécku a dies lustricus v Ríme), prijatie otcom, ktorý tak potvrdil jeho legitimitu. Ďalšia zmena statusu nastávala zrejme medzi polrokom a jedným rokom diet'at'a v súvislosti s erupciou dočasného chrupu, odstavením a zavádzaním príkrmov, rozvojom reči a pod., čo sa odráža aj v pohrebnom ríte. Dôležitost’ prechodových rituálov vyplýva ako z písomných, tak archeologických prameňov. 
Ďalej je podla nášho názoru dôležité rozlišovat' medzi prístupom k det’om, ktoré boli od začiatku chcené a prístupom $\mathrm{k}$ det’om, ktoré boli nechcené. O želané deti, ktoré sa narodili zdravé a splnili všetky predpoklady na prijatie do rodiny, sa rodina d’alej starala s láskou a pokial zomreli, bol ich skon pre rodičov bolestnou stratou. Na druhú stranu deti neželané, postihnuté, bez otca a pod. mohli byt' odložené či zabité, čo však samozrejme neznamená, že minimálne matka nepocit'ovala túto stratu. Vel'mi pravdepodobne to však nebol úzus, ktorý by platil pre neželané deti všeobecne, išlo zrejme o krajné riešenie. Výrazná variabilita v zaobchádzaní s pozostatkami najmenších detí môže reflektovat’ tieto dve odlišné percepcie skupiny detí chcených a nechcených.

Archeologické pramene nám poskytujú najmä náhl’ad na pohrebné zvyky. Na konkrétnych lokalitách môžeme sledovat' postupnú zmenu pohrebného rítu týkajúceho sa nakladania s telami zomrelých detí rôzneho veku a statusu (napr. pohrebiská v Abdére), podobne ako je možné pozorovat' vývoj názorov v uvádzaných písomných prameňoch pochádzajúcich zo širšieho časového úseku. Pochovávanie poukazuje na liminálny status novorodencov (nálezy pozostatkov v studniach - Atény, Mesénia, italské Lugnano, galorímské lokality - Sallèles d’Aude, Langeais etc.). Disponujeme príkladmi, ked’ dokonca aj fetusy boli pochované regulárne (pohrebisko Kylindra na ostrove Astypalaia), čo ani v dnešnej dobe nie je samozrejmost'ou.

Rozporuplnost' percepcie najmenších detí vyplývajúca z analyzovaných prameňov zrkadlí komplexitu spoločnosti, z tohto dôvodu je vhodné do budúcna skúmat’ tento fenomén vo vzt’ahu ku konkrétnej spoločnosti v užšom časovom a geografickom rámci. Z vyššie uvedeného je zrejmé, že náhlad na malé deti v antike výrazne kontrastuje s náhl’adom súčasnej západnej spoločnosti, pričom sa tento postoj menil s narastajúcim vekom diet’at’a. Vo všeobecnosti však možno skonštatovat', že v antike, ale pravdepodobne aj v prehistorických, iných historických a tradičných spoločnostiach mali novorodenci a malé deti špeciálne postavenie $\mathrm{v}$ rámci danej komunity, ktoré nie je možné primárne interpretovat' ako nedôležité.

Poznámka: Predložená práca vznikla s finančnou podporou projektu VEGA 1/0100/19 a Ministerstva kultury ČR v rámci inštitucionálneho financovania dlhodobého koncepčného rozvoja výskumnej organizácie Národní muzeum (DKRVO 2019-2023/17.IV.a, 00023272).

\section{Pramene}

Aristoteles Gen. An. = Aristoteles: De Generatione Animalium (Ge. An.). Translation Platt, A., 2012: On the Generation of Animals by Aristotle. <Dostupné na: http://ebooks.adelaide.edu.au/a/aristotle/generation> [Navštívené 23. 3. 2020].

Aristoteles Hist. Anim. $=$ Aristoteles: Historia Animalium. $<$ Dostupné na: https: $/ /$ archive.org/details/historiaanimaliu00aris_0/page/n337/mode/2up > [Navštívené 23. 3. 2020].

Aristoteles, Phys. = Aristotle: Physics. Translation Wicksteed, Ph. H. - MacDonald Cornford, F., London, 1929. <Dostupné na: https://archive.org/details/in.ernet.dli.2015.183335/page/n243/mode/2up > [Navštívené 24. 1. 2020].

Aristoteles Politika $=$ Aristoteles: Politika. Preklad Špaňár, J. Bratislava, 2009.

Aristoteles De anima $=$ Aristoteles: $\mathrm{O}$ duši. Preklad Kř́ž , A. Praha, 1995.

Cic., Tusc $=$ Cicero, Marcus Tullius: The Tusculan Disputations. Translation Peabody, A. P. Boston, 1886. $<$ Dostupné na: https://archive.org/details/cicerostusculand00cice/page/68/mode/2up> [Navštívené 21. 2. 2020].

Fulgentius $=$ Fulgentius, Fabius Planciades: The Explanation of Obsolete Words Translation Whitbread, L. G.: Ful- 
gentius, the Mythographer. Ohio, 1971.

Gal. De Sem. = Galénos: Claudii Galeni Opera Omnia. Translation amd ed. Kühn, C.G. (ed.) Leipzig, 1821-1833. <Dostupné na: https://archive.org/details/hapantaoperaomni01galeuoft/page/n11/mode/2up > [Navštívené 24. 1. 2020].

Hipp., De Nat. Puer. = Hippocrates: De natura pueri. Littré, E. (ed.): Oevres complètes d’Hippocrate. 10 zv. Paris, 1839-1861.

Juvenalis $=$ Juvenalis, Decimus Iunius: Satirae. Translation Wright, H. P.: Juvenal. Boston, 1901. <Dostupné na: http://archive.org/stream/juvenal03wriggoog\#page/n262/mode/2up> [Navštívené 21. 2. 2020].

Lucr., De rer = Lucretius Carus Titus: On the Nature of the Things (De rerum natura). Translation Smith Ferguson M. Indianapolis, 2001.

Platón Ústava/ Resp = Platón: Ústava. Preklad Špaňár, J. Bratislava, 1980.

Platón, Leg. = Plato: Laws. Translation Burry, L. G.: Plato - Laws I. London, 1926. <Dostupné na: https://archive. org/details/platowithenglish91platuoft/page/272/mode/2up> [Navštívené 24. 3. 2020].

Platón, Tht. = Plato: Theaetetus (Tht). Translation MacDonald Cornford, F.: Plato' Theaetetus. Cambridge, 1957. <Dostupné na: https://archive.org/details/theaetetus00plat/page/80/mode/2up> [Navštívené 24. 2. 2020].

Plinius Starší, Nat. Hist. = Plínius Starší: Naturalis historia. Preklad Němeček, F., Antická knihovna. Praha, 1974.

Plutarchos, Bioi paralléloi = Plutarch's Lives. The Life of Lycurgus. Translation Perrin, B. London, 1914. <Dostupné na: http://penelope.uchicago.edu/Thayer/E/Roman/Texts/Plutarch/Lives/Lycurgus*.html > [Navštívené 23. 3. 2020].

Plutarchos, Bioi paralléloi = Plutarchos: Plutarch's Lives. The Life of Numa. Translation Perrin, B. London, 1914. <Dostupné na:https://penelope.uchicago.edu/Thayer/E/Roman/Texts/Plutarch/Lives/Numa*.html> [Navštívené 23. 3. 2020].

Plutarchos, Quaest. Rom. = Plutarchos: Moralia - Quaestiones Romanae. Plutarch's Moralia. Roman Questions. Translation Babbit F. C. London, 1928.

Plutarchos, Mor. = Plutarchos: Moralia - Consolatio ad Uxorem. <Dostupné na: http://penelope.uchicago.edu/ Thayer/E/Roman/Texts/Plutarch/Moralia/Consolatio_ad_uxorem*.html > [Navštívené 23. 3. 2020].

Seneca De Ira = Seneca, Lucius Annaeus: De Ira. Moral Essays: volume 1. Translation Basore, J. W. London and New York, 1928. <Dostupné na: http://www.perseus.tufts.edu/hopper/text?doc=Perseus\%3Atext\%3A2007.01.0014\%3Abook\%3D1\%3Achapter\%3D15\%3Asection\%3D2 [Navštívené 21. 2. 2020].

Soranus: Gynecology (Gynaecia). Translation Temkin, O. - Eastmen, N. J. - Edelstein, L. - Guttmacher, A. F. Baltimore, 1956.

Tertulián = Tertullianus, Quintus Septimus: De anima. P Translation Waszink, J. H. Leiden - Boston, 2010.

Tertulián = Tertulianus, Quintus Septimus: Apology - De Spectaculis. Translation Glover, T. R. London, 1977.

Ulpian., Dig. = Ulpianus Domitius: The Digest of Justinian, Vol. 2. Translation and ed. Watson, A. Philadelphia, 
1985 <Dostupné na: http://nbls.soc.srcf.net/files/files/Civil\%20II/Texts/Digest\%20of\%20Justinian,\%20Volume $\% 202 \% 20($ D.16-29).pdf > [Navštívené 23. 2. 2020].

Varro, De re rustica = Varro, Marcus Terentius: De re rustica. Liber Tertius. Translation Hooper, W. D. - Ash, H. B., 1934. Harvard, 1934. <Dostupné na: http://penelope.uchicago.edu/Thayer/L/Roman/Texts/Varro/de_Re_ Rustica/3*.html> [Navštívené 23. 2. 2020].

\section{Bibliografia}

Backe-Dabmen, A. 2006: Innocentissima Aetas. Römische Kindheit im Spiegel literarischer, rechtlicher und archäologischer Quellen des 1. Bis 4. Jahrhunderts n. Chr. Mainz am Rhein.

Baills-Barré, N. 2016: Les enfants en bas âge en Gaule romaine: identification des lieux d'inhumation et des marqueurs matériels. In: Bourrouilh, A. - Haidar Vela, N. - Pierre-Emmanuel, P. (dir.): Appréhension et qualification des espaces au sein du site archéologique. Paris: Éditions de la Sorbonne. <Dostupné na: http://books.openedition. org/psorbonne/4735> [Navštívené 2. 4. 2020]

Beilke-Voigt, I. 2007: Das „Opfer“ im archäologischen Befund. Studien zu den sog. Bauopfern, kultischen Niederlegungen und Bestattungen in ur- und frühgeschichtlichen Siedlungen Norddeutschlands und Dänemarks. Rahden - Westfalen.

Blaizot, F. - Alix, G. - Ferber, E. 2003: Le traitement funéraire des enfants décédés avant un an dans l'Antiquité: études de cas, Bulletins et mémoires de la Société d’Anthropologie de Paris, 15 (1-2), 49-77.

Bonsall, L. 2013: Infanticide in Roman Britain: A Critical Review of the Osteological Evidence, Childhood in the past 6/2,73-88.

Bourbu, C. - Themelis, P. 2010: Child Burials at Ancient Messene. In: L'Enfant et la mort dans l'Antiquité I. Nouvelles recherches dans les nécropoles grecques. Le signalement des tombes d'enfants. Actes de la table ronde internationale, École française d'Athènes, 29-30 mai 2008, Athènes. Paris, 111-128.

Cambiano, G. 2005: Cesta k dospělosti. In: Vernant, J. P. (ed.): Řecký člověk a jeho svět. Praha, 77-103.

Caroll, M. 2011: Infant Death and Burial in Roman Italy, Journal of Roman Archaeology 24, 99-120.

Caroll, M. 2018: Infancy and Earliest Childhood in the Roman World. A Fragment of Time. Oxford.

Clement, A. - Hillson, S. - Michalaki-Kolia, M. 2008: The ancient cemeteries of Astypalaia, Greece. Archaeology International 12, 17-21.

Czachorowski, M. 2018: Abortion in the Universal Encyclopedia of Philosophy. Studia Gilsoniana 7, no. 4, 567-578.

Dasen, V. 2003: Les amulettes d'enfants dans le monde gréco-romain, Latomus 62(2), 275-89.

Dasen, V. 2008: All Children are Dwarfs. Medical discourse nad iconography of children's bodies. Oxford Journal of Archaeology 27/1, 49-62.

Dasen, V. 2009: Roman birth rites of passage revisited. Journal of Roman Archaeology 22, 199-214. 
Dasen, V. 2011: Childbirth and Infancy in Greek and Roman Antiquity. In: Rawson, B. (ed.): A Companion to Families in the Greek and Roman Worlds, Oxford: Blackwell, 291-314.

Dasen, V. 2013a: Becoming Human: From the Embryo to the Newborn Child. In: Evans Grubbs, J. - Parkin, T. (eds.): The Oxford Handbook of Childhood and Education in the classical world, Oxford University Press, 17-39.

Dasen, V. 2013b: Naissance et petite enfance dans l'Antiquité. Nouvelles approches. Dossiers d'archéologie 356, 2-7.

Duday, H. - Laubenheimer, F. - Tillier, A.-M. 1995: Sallèles d'Aude: nouveau-nés et nourrissons gallo-romains. Presses Univ. Franche-Comté.

Evans Grubbs, J. 2013: Infant Exposure and Infanticide. In: Evans Grubbs, J. - Parkin, T. (eds.): The Oxford Handbook of Childhood and Education in the classical world, Oxford University Press, 83-107.

Evans Grubbs, J. - Parkin, T. (eds.) 2013: The Oxford Handbook of Childhood and Education in the classical world. Oxford University Press.

Fellman, R. 1993: Texte zum Grabrecht und Grabbrauch. In: Struck, M. (ed.): Römerzeitliche Gräber als Quellen zu Religion, Bevölkerungsstruktur und Sozialgeschichte. Internationale Fachkonferenz vom 18. - 20. Februar 1991 im Institut für Vor- und Frühgeschichte der Johannes Gutenberg-Universität Mainz. Mainz, 11-15.

Garland, R. 2013: Children in Athenian Religion. In: Evans Grubbs, J. - Parkin, T. (eds.): The Oxford Handbook of Childhood and Education in the Classical World, Oxford University Press, 207-226.

Gennep, A. van 1996: Přechodové rituály. Systematické studium rituálů. Praha: Lidové noviny.

Gjerstad, E. 1954: Suggrundaria. In: Lullies, R. (Hrsg.): Neue Beiträge zur klassischen Wissenschaft. Festschrift zum 60. Geburtstag von B. Schweitzer. Stuttgart, 291-296.

Golden, M. 1988: Did the Ancients Care When Their Children Died? Greece \& Rome, 2nd Ser., Vol. 35, No. 2, 152-163.

Golden, M. 1990: Children and Childhood in Classical Athens. JHU Press.

Golden, M. 2013: Children in Latin Epic. In: Evans Grubbs, J. - Parkin, T. (eds.): The Oxford handbook of childhood and education in the classical world. Oxford University Press, 249-263.

Gowland, R. 2016: Ideas of childhood in Roman Britain: the bioarchaeological and material evidence. In: Millett, M. - Revell, L. - Moore, A. (eds): The Oxford handbook of Roman Britain. Oxford, 303-320.

Graham E.-J. 2016: Wombs and Tombs in the Roman World, Material Religion, 12:2, 251-254.

Halcrow, S. E. - Tayles, N. - Elliott, G. E. 2018: The Bioarchaeology of Foetuses. In: Han, S. - Betsinger, T. K. - Scott, A. B. (eds.): The Anthropology of the foetus. New York: Bergahn Books, 83-111.

Hladiková, K. 2018: Protection of Children? A Case Study from the Early Iron Age Cemetery of Quattro Fontanili, Veii. Studia Hercynia 22/1, 56-76.

Hope, M. V. 2007: Death in the Ancient Rome. A Sourcebook. Oxon. 
Kallintzi, K. - Papaikonomou, I.-D. 2010: La présence des enfants dans les nécropoles d'Abdère. In: Guimier-Sorbets, A.-M. - Morizot, Y. (éds.): L’Enfant et la mort dans l'Antiquité I. Nouvelles recherches dans les nécropoles grecques. Le signalement des tombes d'enfants. Actes du 1er colloque EMA, Athènes, École Française d'Athènes, 29-30 mai 2008. Travaux de la Maison René-Ginouvès 12. Paris: De Boccard, 129-159.

Karamanou, M. - Tsoucalas, G. - Creatsas, G. - Androutsos, G. 2013: The effect of Soranus of Ephesus (98-138) on the work of midwives. Women and Birth 26, 226-228.

Kerényi, K. 1996a: Mytologie Řeků I. Příběhy bohů a lidí. Praha.

Kerényi, K. 1996b: Mytologie Řeků II. Příběhy héróů. Praha.

Koštalová, L’. - Kovács, L. et al. 2005: Úvod do pediatrie. Skriptá pre nelekárske smery. Lekárska fakulta Univerzity Komenského v Bratislave. Bratislava.

Köves Zulauf, T. 1990: Römische Geburtsriten. München.

Krausse, D. 1998: Infantizid. Theoriegeleitete Überlegungen zu den Eltern-Kind-Beziehungen in ur- und frügeschichtlicher und antiker Zeit. In: Müller-Karpe, A. - Brandt, H. et al. (eds.): Studien zur Archäologie der Kelten, Römer und Germanen in Mittel- und Westeuropa. Alfred Haffner zum 60. Geburtstag gewidmet. Rahden/ Westfalen, 313-52.

Krausse, D. 2002: Kinder als Opfer - Kinderopfer. Zur Interpretation antiker und prähistorischer „Sonderberstattungen“" von Säuglingen und Kleinstkindern. In: Alt, K. W. - Kemkes-Grottenthaler, A. (Hrsg.): Kinderwelten. Anthropologie - Geschichte - Kulturvergleich. Böhlau Verlag. Köln, 171-187.

Lewis, M. 2007: The Bioarchaeology of Children: Perspectives from Biological and Forensic Anthropology. Cambridge: Cambridge University Press.

Lindenlauf, A. 2001: Thrown Away Like Rubbish - Disposal of the Dead in Ancient Greece, Papers from the Institute of Archaeology 12, 86-99.

Liston, M. A. - Rotroff, S. I. 2013: Babies in the well: Archaeological evidence for newborn disposal in Hellenistic Greece. In: Evans Grubbs, J. and Parkin, T. (eds.) The Oxford handbook of childhood and education in the classical world, Oxford University Press, 62-82.

Malamitsi-Puchner, A. 2017: Preterm birth in ancient Greece: a synopsis, The Journal of Maternal-fetal Neonatal Medicine 30(2), 141-143.

Malamitsi-Puchner, A. - Briana, D. D. 2017: Ancient Greek view of perinatal risk issues: from myth to reality. Journal of Pediatric and Neonatal Individualized Medicine 2017, 6 (2), 1-3.

Mays, S. 1993: Infanticide in Roman Britain, Antiquity 67, 883-888.

Mays, S. 2000: The Archaeology and History of Infanticide, and its Occurence in Earlier Britisch Populations. In: Sofaer Derevenski, J. (ed.): Children and Material Culture. London, 180-188.

Mays, S. - Eyers, J. 2011: Perinatal infant death at the Roman villa site at Hambleden, Buckinghamshire, England. Journal of Archaeological Science 38, 1931-1938. 
Mays, S. - Robson Brown, K. - Vincent, S. - Eyers, J. - King, H. - Roberts, A. 2014: An Infant Femur Bearing Cut Marks from Roman Hambleden, England. International Journal of Osteoarchaeology 24 (1), 111-115.

Melotti, M. 2005: Crossing the Worlds: Space, Myths and Rites of Passage in Ancient Greek Culture. In: Mustakallio, K. - Hanska, J. - Sainio, H. L. - Vuolanto, V. (eds.): Hoping for Continuity. Childhood, Education and Death in Antiquity and the Middle Ages. Rome, 203-214.

Moore, A. 2009: Hearth and Home: The Burial of Infants within Romano-British Domestics Contexts. Childhood in the Past 2/1, 33-54.

Muggia, A. 2004: Impronte nella Sabbia: Tombe infantili e di adolescenti dalla necropolis di Valle Trebba a Spina. Quaderni di Archeologia dell’Emilia Romagna 9. Firenze.

Müller, K. E. 1992: Kindheitsvorstellungen. In: Müller, K. E. - Treml, A. K. (Hrsg.): Ethnopädagogik. Sozialization und Erziehnug in traditionellen Gesellschaften. Eine Einführung, 11-30.

Papaikonomou, I.-D. 2013: La jeune fille morte en couches: Un cas de maternité précoce, souhaitée ou avortée, d'après les témoignages des sépultures, Mètis - Anthropologie des mondes grecs anciens, Daedalus/EHESS, 2013, Dossier: Mères et maternités en Grèce ancienne, N.S.11, 109-144.

Parkin, T. 2013: The Demography of Infancy and Early Childhood in the Ancient World. In: Evans Grubbs, J. Parkin, T. (eds.): The Oxford handbook of childhood and education in the classical world, Oxford University Press, 40-61.

Pearce, J. 2001: Infants, Cemeteries and Communities in the Roman Provinces. In: Davies, D. - Gardner, A. - Lockyear, K. (eds): TRAC 2000: Proceedings of the Tenth Annual Theoretical Roman Archaeology Conference, London 2000. Oxford: Oxbow Books, 125-142.

Ploss, H. 1911: Das Kind in Brauch und Sitte der Völker (Hrsg. B. Renz). Leipzig.

Rawson, B. 2003: Children and Childhood in Roman Italy. Oxford.

Sameiro Barroso, M. 2013: Post-mortem Cesaean section and embryotomy: myth, medicine, and gender in Greco-Roman Culture. Acta Medico-Historica Adriatica 11/1, 75-88.

Scott, E. 1999: The Archaeology of Infancy and Infant Death. BAR International Series 819. Oxford: Archaeopress.

Smith, P. - Kabila, G. 1992: Identification of infanticide in archaeological sites: A case study from the LateRoman-Early Byzantine periods at Ashkelon, Israel. Journal of Archaeological Science 19, 667-675.

Sommer, M. - Sommer, D. 2015: Care, socialization and play in ancient Attica. A developmental childhood archaeological approach. Aarhus.

Stearns, P. N. 2011: Childhood in World History. New York.

Stol, M. 2000: Birth in Babylonia and the Bible: its Mediterranean setting. Cuneiform Monographs 14.

Struck, M. 1993: Kinderbestattungen in romano-britischen Siedlungen: der archäologische Befund. In: Struck, M. (ed.): Römerzeitliche Gräber als Quellen zu Religion, Bevölkerungsstruktur und Sozialgeschichte: Internationale Fachkonferenz, Mainz 18.-20. Februar 1991 im Institut für Vor- und Frühgeschichte des Johannes Guten- 
berg-Universität Mainz, 313-318.

Tsoucalas, G. - Sgantzos, M. 2017: Calculating Pregnancy's Duration in Ancient Greece. Gestational, or Fetal Age? Obstetrics \& Gynecology International Journal 6/3, 00209.

Vélová, L. 2018: Úvod do „archeologie dětstvi“. Acta Musei nationalis Pragae - Historia 72/1-2, 62-77.

Vélová, L. - Hladiková, K. - Dañová, K. (v tlací): The Little Ones in the Early Bronze Age: Foetuses, Newborns and Infants in the Únětice Culture in Bohemia, Moravia and Slovakia. In: Rebay-Salisbury, K. - Pany-Kucera, D. (eds.): Ages and Abilities: The Stages of Childhood and their Social Recognition in Prehistoric Europe and Beyond. SSCIP monograph book.

\section{Summary}

The issue of children and childhood has been marginalised considerably in historical sciences and archaeology. In recent decades, however, more and more researchers have dealt with this topic, especially female ones. As a result of this development, works focused on partial aspects and phenomena of the issue of children have appeared (Dasen 2003, 2004, 2008 etc.). Archaeology is no exception. Although the possibilities of (re)constructing the status and perception of children using only archaeological sources are relatively limited, cooperation with other scientific disciplines has brought inspiring results. The worldwide boom of "archaeology of childhood" has brought the possibilities and the need to study the youngest age group in more detail. Rare findings of the remains of the youngest children, i.e. unborn foetuses and newborns, have been increasing (see, for example Vélová - Hladiková - Dañová, in print), which is undoubtedly related to modern research approaches and methods. New archaeological finds allow confrontation of the corresponding written sources and rethinking of the fundamental society-wide topics, such as the origin of life, the status of foetuses and newborns, disabled individuals and the status of pregnant women and mothers, etc.

For illustration, to convey the wide range of perceptions of young children in a particular society, we used a selection of ancient written sources and associated archaeological finds of children remains. The paper aims to show a considerable variability in the perception of children of different age categories, especially the youngest children from unborn/aborted foetuses to infants, in antiquity. The lack of sources describing or depicting young children and the often-mentioned shortage of their remains in archaeological sources (missing children at cemeteries and settlements) are relatively often interpreted as the absence of love for children, or their insignificance for the society until a certain age.

The plurality of opinions on the perception of foetuses and young children by ancient authors is determined by the nature of written sources, which do not present a cohesive picture, but rather a mosaic of different perspectives depending on the personality of a writer, usually a male, which come from a wider chronological and geographical framework. The works of ancient authors contain, for example, the distinction of stages of foetus formation, pregnancy, childbirth (Hippocrates, Galenus, Soranus) and also the debate about the soul of foetuses and abortions (e.g. Plato, Aristotle, Cicero, Tertullian). They also contain recommendations regarding the appropriate age of girls for a wedding and subsequent conception. Ancient physicians were aware of the risks associated with pregnancy and childbirth in very young mothers.

Older scientific literature that analyses ancient sources tends to present children, childhood and - in the context of the paper - the youngest children negatively. The reflections of scholars (e.g. Plato, Aristotle) about children as imperfect beings compared e.g. to animals led to a view of their inferior status in antiquity. Official bans on mourning over the death of children were then interpreted as a lack of parental love, whose absence was attributed to high infant mortality (Rawson 2003; Golden 1988; Caroll 2011; 2018; Sommer - Sommer 2015 and others). In recent years, however, there has been a noticeable reassessment of this predominantly negative view of children (Caroll 2018 with other literature), although these views still appear or are taken over with bias even in the recent literature. Of course, 
this is related to several aspects, but it is above all determined by the influence of our contemporary view of, for example, the practice of exposure or infanticide without considering the broader context.

To address this issue, it is necessary to distinguish between two levels of perception: the first one represents the public sphere following the official interests of the state, i.e. the level of the society's relations with children, which is reflected in philosophical, legal or medical literature. The second level, represented by the relations between parents and children, is manifested mainly in private correspondence, poetry, etc. (e.g. Cicero, Lucretius, Fronto, Ausonius). In general, children were considered as successors to the family line, their task was to take care of parents in old age; lower classes expected to have an economic benefit already during the childhood. A child's survival depended on its biological birth, but above all on its social inclusion, acceptance by the father, who thus confirmed its legitimacy. The importance of rites of passage is clear from both written and archaeological sources.

Furthermore, in our view, it is important to distinguish between the approach to children who were wanted from the beginning and the approach to children who were unwanted. The family took care of the desired children who were born healthy and met all the conditions for acceptance in the family, and if they died, their death was a painful loss for their parents. On the other hand, unwanted or disabled children, or children without a father etc. could be exposed or killed. Most likely, however, this was not a custom that applied to unwanted children in general, it was probably an extreme solution. The high variability in the treatment of the remains of the youngest children may reflect these two different perceptions of the group of wanted and unwanted children.

Archaeological sources provide us with an insight into burial customs, where at specific sites we observe a gradual change in the burial rite concerning the treatment of the bodies of deceased children of different age and status (e.g. the burial ground in Abdera). It is also possible to see the development of views in the mentioned written sources from a wider time period. Burial indicates the liminal status of newborns (finds of remains in wells - Athens, Mesenia, Gallo-Roman sites - Sallèles d'Aude, Langeais). However, there are examples where even foetuses were buried regularly (the Kylindra burial ground on the island of Astypalaia), which is not a matter of course even today. The contradictions in the perception of youngest children resulting from the analysed sources reflect the complexity of the society; therefore, it is appropriate to study this phenomenon in the future in relation to a particular society in a narrower chronological and geographical framework. 